\title{
Survey of medicinal plants used in the region Northeast of Brazil
}

\author{
Maria de Fátima Agra,* Kiriaki Nurit Silva, Ionaldo José Lima Diniz Basílio, Patrícia \\ França de Freitas, José Maria Barbosa-Filho \\ Universidade Federal da Paraíba, Laboratório de Tecnologia Farmacêutica, Caixa Postal 5009, 58051-970 \\ João Pessoa-PB, Brazil
}

\begin{abstract}
RESUMO: "Levantamento das plantas medicinais usadas na região Nordeste do Brasil". Este trabalho teve como objetivo um levantamento das plantas e dos seus usos como medicinais, as quais são utilizadas com fins terapêuticos na região Nordeste do Brasil. A área de estudo é reconhecida por uma rica biodiversidade, principalmente de plantas e de hábitats, abrangendo desde a Floresta Amazônica, Floresta Atlântica, sistemas de mangues e dunas costeiras, até florestas secas e savanas. Como resultados, foram registrados um total de 650 espécies pertencentes a 407 gêneros e 111 famílias, e suas informações etnomedicinais. A diversidade florística é dominada por vegetais superiores e apenas cinco espécies das famílias Aspleniaceae, Cyatheaceae, Equisetaceae, Polypodiaceae e Selaginellaceae pertencem ao grupo das Pteridófitas, que corresconde a menos que $1 \%$ do total das espécies registradas. Este estudo sugere a grande importância da investigação das espécies farmacologicamente ainda não estudadas, uma vez que seus usos populares estão registrados.
\end{abstract}

Unitermos: Etnomedicina, etnobotânica, plantas medicinais, medicina popular, Nordeste do Brasil.

\begin{abstract}
This work has the objective a survey of the species of plants and their uses as medicinal, which are utilized for therapeutic purposes in Northeast region of Brazil. The area of study is recognized by a rich diversity of species of plants and habitats that ranges from Rainforest, Atlantic Forest, coastal dunes systems and mangroves, to dry forests and savannas. As results, a total of 650 species belonging to 407 genera and 111 families were recorded and also their ethnomedicinal information. The floristic diversity is dominated by higher plants and only five species belonging to the families Aspleniaceae, Cyatheaceae, Equisetaceae, Polypodiaceae and Selaginellaceae were reported belonging to the Ferns group, which correspond to less than 1 $\%$ of the total of the registered species. This study aims at emphasizing the greatest importance of investigation of those species that have not been subject of pharmacological study, although their popular uses have already been reported.
\end{abstract}

Keywords: Ethnomedicine, ethnobotany, medicinal plants, popular medicine, Northeast of Brazil.

\section{INTRODUCTION}

The traditional Medicine is used in all parts of the world and has a rapidly growing economic importance, mainly by the use of medicinal plants that have a respectable position today, especially in the developing countries (Agra et al. 2007a), where the modern health service is limited and represent the only accessible treatment.

According to the World Health Organization (WHO, 1999), the current estimative suggests that many developed countries have a great proportion of the population making use of traditional practice of health, especially the use of the medicinal plants. Although the access to the modern medicine is available in these countries, the use of medicinal herbs has kept its popularity for historical and cultural reasons. On the other hand, in the developing countries, $65-80 \%$ of the population depends exclusively on the medicinal plants for basic cares of health, up to $80 \%$ of the population in Africa, $71 \%$ in Chile and $40 \%$ in Colombia, inter alia.

Medicinal plants represent an important health and economic component of biodiversity and also conservation and sustainable use, according to Rhaman et al. (2004). Information on the traditional knowledge or ethnic groups of medicinal plants and their uses would represent a vital role in the discovery of novel products from plants as chemotherapeutic agents (Almeida et al., 2001; Silva et al., 2003; Rocha et al., 2005; BarbosaFilho et al., 2006, 2007, 2008). The surrounding plants form an integral part of culture of these people and the information about plants is passed on from generation to generation (Agra et al., 2007a, b).

The traditional healers of medicinal plants called 
as "raizeiros" by the people of the Northeast region of Brazil have a commendable knowledge of the medicinal plants that grow around them (Agra et al., 2005, 2007a). This knowledge of traditional healing practices mainly by the use of wild plants is now fast disappearing due to modernization and the tendency to change their traditional for more actual lifestyle. There is an urgent need to study and recorder this precious knowledge of the uses of plants as herbal remedies that are declined due to scarcity of species, which is caused mainly by the human activity coupled with the long period of the dry season. In this context, those conservation and scientific verification of rare and lesser known medicinal plants assume greater significance.

The study of traditional uses of plants and their products in the Northeast region of Brazil has been progressively increasing during the last few years, and has enabled the collection of a significant body of knowledge, which is referred by Agra et al. (2007a, $\mathrm{b}$, and c). Although, there are still many gaps in our knowledge of ethnomedicinal plant uses in this region, some of the main traits are presented here.

\section{MATERIAL AND METHODS}

\section{Study area}

The general area of the Brazilian Northeast has $1,561,177.8 \mathrm{~km}^{2}$ and extends from about $02^{\circ} 54^{\prime}$ to $17^{\circ} 21^{\prime} \mathrm{S}$ and from $35^{\circ}$ to $46^{\circ} 30^{\prime} \mathrm{W}$ that includes nine States: Maranhão, Piauí, Ceará, Rio Grande do Norte, Paraíba, Pernambuco, Alagoas, Sergipe and Bahia. It is a region with a rich plant diversity habitats ranging from rainforest, occurring in North of Maranhão, Atlantic Forest, coastal dunes systems and mangroves, to dry forests and savannas. The principal ecosystem of the Northeast of Brazil is the biome "caatinga", an Indian word, meaning "open forest", from its appearance during the dry season (Andrade-Lima, 1981; Ab'Saber, 1980; Lleras, 1997). It consists of extensive semi-arid plains found mainly in Northeast region from Piauí to North of Minas Gerais.

\section{Format}

This study is focused on a survey of literature (Braga, 1960; Agra, 1982, 1996; Agra et al., 1994, 1996, 2005, 2007a, b, c; Baracho \& Agra, 1995; Rêgo, 1995; Agra \& Bhattacharyya, 1999; Costa et al., 2001, 2002; Freitas \& Agra, 2002; Emperaire, 1983; Monteiro et al., 2006; Albuquerque et al., 2007; Basílio et al., 2005; David et al., 2007) of the medicinal uses of native, naturalized and cultivated plants species, which are utilized for therapeutic purposes in all States of Northeast of Brazil extending from Maranhão to Bahia. The information of the plants and their ethnomedicinal uses are compiled in the Table 1, which provides the botanical family, scientific names of species (the specific binomial). The vernacular names, parts used and popular indication and uses are also presented. The abbreviations of the authors follow Brummitt \& Powell (1992). The cultivated species in Northeast of Brazil are indicated by only one asterisk, and the species that are imported from outside of Brazil have two asterisks.

\section{RESULTS AND DISCUSSION}

The investigation of the plants known by the ethnomedicinal uses in Northeast of Brazil revealed a total of 650 species and 407 genera belonging to 111 families. Of these, about 126 species referred by its medicinal uses are exotic and cultivated in the region, corresponding to about $20 \%$ of the total. The floristic diversity is dominated by higher plants and only five species were reported belonging to the Ferns group that are: Asplenium auritum Sw., Cyathea microdonta (Desv.) Domin, Equisetum sp., Microgramma vacciniifolia (Lagsd. \& Fisch.) Copel. and Selaginella convoluta Spreng. belonging to the families Aspleniaceae, Cyatheaceae, Equisetaceae, Polypodiaceae and Selaginellaceae, respectively, which correspond to less than $1 \%$ of the total of the registered species.

The predominance of higher plants used for medicinal purposes in Northeast of Brazil confirms our results in previous work (Agra et al., 1994, 1996, 2005, 2007a, b, c; David et al., 2007) and also have been documented by other authors in the region (Emperaire, 1983; Costa et al., 2001, 2002; Luna et al., 2005; Monteiro et al., 2006; Albuquerque et al., 2007) and in different areas of Brazil (Souza et al., 2004; Luna et al., 2005; Mendes \& Carlini, 2007), as well as in other countries around the world such as Saudi Arabia (Rahman et al., 2004), Bolıvia (Macía et al., 2005), Italy (Scherrer et al., 2005), Morocco (Tahraoui et al., 2007), inter alia.

Most plants are used internally, and are prepared in the form of decoction, infusion and maceration. The form used as juice was referred for a few species mainly for the species that are indicated against verminoses and cough like Chenopodium ambrosioides L. and Mentha sp., respectively. According to Agra et al. (2007b), some preparations are called as "garrafada" (bottled) and constitute a mixture of different plants, mainly roots and stem-barks, which are macerated for a few days to one week in wine or in an alcoholic local drink called "cachaça". Other recipes are prepared as syrups with sugar or honey and are known in the folklore as "lambedor", which are used mainly for illness of children as expectorant or against anemias. Most species have several medicinal uses; various parts used and have different modes of preparation.

\section{CONCLUSION}


Most of the reported species have not been studied for their chemical constituents and/or biological activities. This study aims at emphasizing the greatest importance of investigation of those species that have not been the subject of pharmacological and chemical studies, although their popular uses have been reported.

\section{ACKNOWLEDGMENTS}

This work was supported by grants from the Conselho Nacional de Pesquisa e Desenvolvimento (CNPq) and RENORBIO. Thanks are due to Dulce Gonçalves for her technical support.

\section{REFERENCES}

Ab’Saber AN 1980. O Domínio morfoclimático semi-árido das caatingas brasileiras. Craton Intracraton Escr. Doc. 6: 35 .

Agra MF 1982. Contribuição ao estudo das plantas medicinais na Paraíba. Cienc Cult 33: 64-66.

Agra MF, Rocha EA, Formiga SC, Locatelli E 1994. Plantas medicinais dos Cariris Velhos, Paraíba. Parte I: subclasse Asteridae. Rev Bras Farm 75: 61-64.

Agra MF 1996. Plantas da medicina popular dos Cariris Velhos, Paraíba, Brasil: espécies mais comuns. João Pessoa: Editora União.

Agra MF, Locatelli E, Rocha EA, Baracho GS, Formiga SC 1996. Plantas medicinais dos Cariris Velhos, Paraíba. Parte II: subclasses Magnoliidae, Caryophyllidae, Dilleniidae e Rosidae. Rev Bras Farm 77: 97-102.

Agra MF, Bhattacharyya J 1999. Ethnomedicinal and phytochemical investigation of the Solanum species in the Northeast of Brazil. In: Nee, M., Symon, D.E., Lester, R.N., Jessop, J.P. (editors) Solanaceae IV. Kew: Royal Botanic Gardens, p.341-343.

Agra MF, Freitas PF, Câmara CA, Silva TMS, Almeida RN, Amaral FMM, Almeida MZ, Medeiros IA, Moraes MO, Barbosa-Filho JM, Nurit K, Oliveira FS, Freire KRL, Morais LCSL, Rêgo TJAS, Barros RFM 2005. Medicinais e produtoras de princípios ativos. In: Sampaio, E.V.S.B., Pareyn, F.G.C., Figueirôa, J.M., Santos-Jr, A.G. (editores) Espécies da Flora Nordestina de Importância Econômica Potencial. Recife: Associação Plantas do Nordeste, p.135-198.

Agra MF, Freitas PF, Barbosa-Filho JM 2007a. Synopsis of the plants known as medicinal and poisonous in Northeast of Brazil. Rev Bras Farmacogn 17: 114140.

Agra MF, Baracho GS, Nurit K, Basílio IJLD, Coelho VPM 2007b. Medicinal and poisonous diversity of the flora of "Cariri Paraibano", Brazil. J Ethnopharmacol 111: 383-395.

Agra MF, Baracho GS, Nurit K, Basílio IJLD, Coelho VPM, Barbosa DA 2007c. Sinopse da flora medicinal do Cariri Paraibano. Oecologia Brasiliensis 11: 323330.

Albuquerque AP, Monteiro JM, Ramos MA, Amorim ELC 2007. Medicinal and magic plants from a public market in Northeastern Brazil. J. Ethnopharmacol 110: 76-91.
Almeida RN, Navarro DS, Barbosa-Filho JM 2001. Plants with central analgesic activity. Phytomedicine 8: 310-322.

Andrade-Lima D 1981. The caatinga dominium. Rev Bras Bot 4: 149-153.

Baracho GS, Agra MF 1995. Etnomedicina da Família Malvaceae nos Cariris Velhos, Paraíba, Brasil. Rev Bras Farm 76: 48-52.

Barbosa-Filho JM, Medeiros KCP, Diniz MFFM, Batista LM, Athayde-Filho PF, Silva MS, Cunha EVL, Almeida JRGS, Quintans-Júnior LJ 2006. Natural products inhibitors of the enzyme acetylcholinesterase. Rev Bras Farmacogn 16: 258-285.

Barbosa-Filho JM, Nascimento-Júnior FA, Tomaz ACA, Athayde-Filho PF, Silva MS, Cunha EVL, Souza MFV, Batista LM, Diniz MFFM 2007. Natural products with antileprotic activity. Rev Bras Farmacogn 17: 141-148.

Barbosa-Filho JM, Alencar AA, Nunes XP, Tomaz ACA, Sena-Filho JG, Athayde-Filho PF, Silva MS, Souza MFV, da-Cunha EVL 2008. Sources of alpha-, beta, gamma-, delta- and epsilon-carotenes: A twentieth century review. Rev Bras Farmacogn 18: 135-154.

Basílio IJLD, Nurit K, Agra MF 2005. Estudo farmacobotânico das folhas de três espécies do gênero Strychnos L. (Loganiaceae) do Nordeste do Brasil. Acta Farm Bonaerense 24: 356-365.

Braga R 1960. Plantas do Nordeste, especialmente do Ceará. $2^{\text {a }}$ Ed. Fortaleza: Imprensa Oficial.

Brummitt RK, Powel CE 1992. Authors of Plant Names. Royal Botanic Gardens, Kew, Great Britain. 732p.

Costa LCB, Moreira RCT, Lucena EARM, Jardim JG 2001. Plantas medicinais mais utilizadas pelas populações da região cacaueira da Bahia. Rev Bras Farm 82: 7377.

Costa LCB, Moreira RCT, Costa RCS, Lucena EARM 2002. Abordagem etnobotânica acerca do uso de plantas medicinais na Vila Cachoeira, Ilhéus, Bahia, Brasil. Acta Farm Bonaerense 21: 205-211.

David JP, Meira M, David JM, Brandão HN, Branco A, Agra MF, Barbosa MRV, Queiroz LP, Giulietti AM 2007. Radical scavenging, antioxidant and cytotoxic activity of Brazilian Caatinga plants. Fitoterapia 78: 215-218.

Emperaire L 1983. La Caatinga du sud-est du Piaui (Brésil): Étude Ethnobotanique. Paris: Éd. Recherche sur les civilisations. $135 \mathrm{p}$.

Freitas PF, Agra MF 2002. Etnomedicina e farmacobotânica das Convolvulaceae da caatinga paraibana, Brasil. Rev Bras Farm 83: 57-65.

Lleras E 1997. Caatinga of North-Eastern Brazil. In: Davis, S.D., Heywood, V.H., Herrera-MacBryde, O., Villa-Lobos, J., Hamilton, A.C. (Eds.) Centres of Plant Diversity. A Guide and Strategy for their Conservation, vol. 3, IUCN Publications Unit, Cambridge, UK, p.393-396.

Luna JS, Santos AF, Lima MRF, Omena MC, Mendonça FAC, Bieber LW, Sant'Ana AEG 2005. A study of the larvicidal and molluscicidal activities of some medicinal plants from Northeast Brazil. $J$ Ethnopharmacol 97: 199-206.

Macía MJ, García E, Vidaurre PJ 2005. An ethnobotanical survey of medicinal plants commercialized in 
the markets of La Paz and El Alto, Bolivia. $J$ Ethnopharmacol 97: 337-350.

Mendes FR, Carlini EA 2007. Brazilian plants as possible adaptogens: an ethnopharmacological surveys of books edited in Brazil. J Ethnopharmacol 109: 493500.

Monteiro JM, Albuquerque AP, Lins-Neto EMF, Araújo EL, Amorim ELC 2006. Use patterns and knowledge of medicinal species among two rural communities in Brazil's semi-arid northeastern region. $J$ Ethnopharmacol 105: 173-186.

Rahman MA, Mossa JS, Al-Said MS, Al-Yahya MA 2004. Medicinal plant diversity in the flora of Saudi Arabia 1: a report on seven plant families. Fitoterapia 75 : 149-161.

Rêgo TJAS 1995. Fitogeografia das plantas medicinais do Maranhão, 2a ed. EDUFMA, São Luis, 133p.

Rocha LG, Almeida JRGS, Macedo RO, Barbosa-Filho JM 2005. A review of natural products with antileishmanial activity. Phytomedicine 12: 514535.

Scherrer AM, Motti R, Weckerle CS 2005. Traditional plant use in the areas of Monte Vesole and Ascea, Cilento National Park (Campania, Southern Italy). $J$ Ethnopharmacol 97: 129-143.

Silva JS, Moura MD, Oliveira RAG, Diniz MFFM, BarbosaFilho JM 2003. Natural products inhibitors of ovarian neoplasia. Phytomedicine 10: 221-232.

Souza GC, Haas APS, von Poser GL, Schapoval EES, Elisabetsky E 2004. Ethnopharmacological studies of antimicrobial remedies in the south of Brazil. $J$ Ethnopharmacol 90: 135-143.

Tahraoui A, El-Hilaly J, Israili ZH, Lyoussi B 2007. Ethnopharmacological survey of plants used in the traditional treatment of hypertension and diabetes in south-eastern Morocco (Errachidia province). $J$ Ethnopharmacol 110: 105-117.

WHO 1999. Monographs on selected medicinal plants. Vol. 1. 
Table 1. Plants names with medicinal or toxic indication, part (s) used and form of way of administration in Northeast of Brazil. Legend: * = species cultivated; ** plant imported.

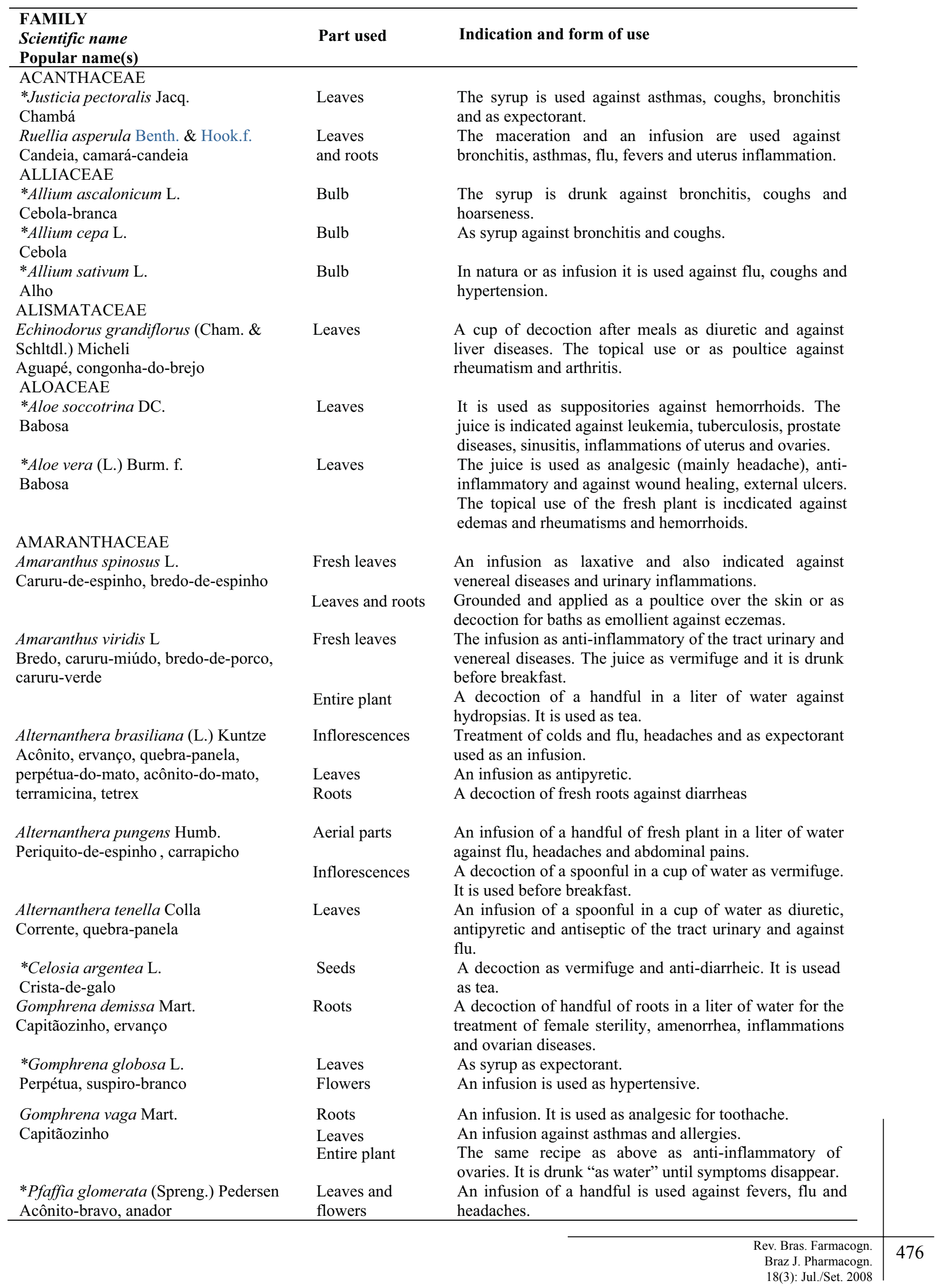




\begin{tabular}{l}
\hline FAMILY \\
Scientific name \\
Popular name(s) \\
\hline AMARYLLIDACEAE \\
Amaryllis belladonna L. \\
Hippeastrum psittacinum (Ker Gawl.) \\
Herb. \\
Alho-bravo, alho-do-mato, açucena-do- \\
campo \\
ANACARDIACEAE \\
Anacardium humile A.St.-Hil. \\
Cajuí, cajuzinho \\
Anacardium occidentale L. \\
Caju, cajueiro
\end{tabular}

Resin and stem-

Spreng.

Gonçalo-alves

*Mangifera indica $\mathrm{L}$.

Manga-espada, mangueira, manga

Myracrodruon urundeuva Alemão

Aroeira, aroeira-do-sertão

Schinopsis brasiliensis Engl.

Braúna

Schinus terebinthifolius Raddi

Aroeira-da-praia

*Spondias mombin $\mathrm{L}$

Cajá, taperebá

*Spondias purpurea $\mathrm{L}$.

Siriguela

Spondias tuberosa Arruda

Imbuzeiro, umbuzeiro

Tapirira guianensis Aubl.

Pau-pombo, fruta-de-pombo

ANNONACEAE

Annona glabra L.

Araticum, araticum do brejo

* Annona montana Macfad.

Graviola, araticum-grande, jaca-do-pará

*Annona squamosa L.

Pinha, ata, fruta-de-conde

Duguetia furfuracea (A.St.-Hil.) Saff.

Araticum-cagão
Fruit and pseudofruit Fruit Pseudofruit

Stem-bark

Resin bark

Bulbs

Bulbs

Leaves

Stem-bark

Stem-bark

Stem-bark

Leaves

Stem-bark and

leaves

Leaves

Leaves

Stem-bark

Fruits

Stem-bark

Leaves

Leaves

Seeds

Stem-bark

\section{Indication and form of use}

The syrup as expectorant and against colds, bronchitis and coughs.

The infusion as aphrodisiac and as syrup it is purgative. The syrup as expectorant and against bronchitis and coughs.

The same indications and uses as Anacardium occidentale $\mathrm{L}$.

In nature are used as food against anemias and as tonic. The juice is indicated against anemia and diabetes. The external use against burnings and ulcers.

The decoction is used as bath against vaginal and external ulcers. The internal use is indicated against diarrheas.

The topical use is indicated against warts coughs and wounds.

The use topic against calluses. The juice against toothaches.

The decoction as stomachic, anti-diarrheic and against genito-urinary inflammations, bronchitis and asthmas. The external use in baths or washes against scabies. In inflammations of ovaries. A decoction or maceration of a handful in a liter of water. It is drunk "as water".

Against external ulcers. The same recipe as above. It is used to wash the ulcerative affections. This species has many other medicinal indication.

As antitussive and against diarrhea and dysenteries. A decoction of handful in a liter of water and sugar as syrup. A spoonful is drunk three to four times until the symptoms disappear.

A decoction of a handful in a liter of water. It is drunk as tea.

The same indications and uses as Myracrodruon urundeuva.

The decoction against diarrheas.

The same use and indication as above

As ophthalmic. A decoction of a cup in a liter of water. It is used as wash for the infected eyes. Also used as digestive and laxative.

As tonic general and as source of vitamins. It is drunk as juice of mature fruits or as a regional drink called "umbuzada", which is made with the green fruits, boiled and mashed and mixed with milk and sugar.

It is used as decoction against diarrheas.

The decoction is used against rheumatism. As vermifuge, it is used before the breakfast.

The juice of fresh leaves against snake bite. The decoction is drunk as water against obesity for lost weight.

The juice of grounded seeds is used in baths against louses.

The same indication and use as above. 


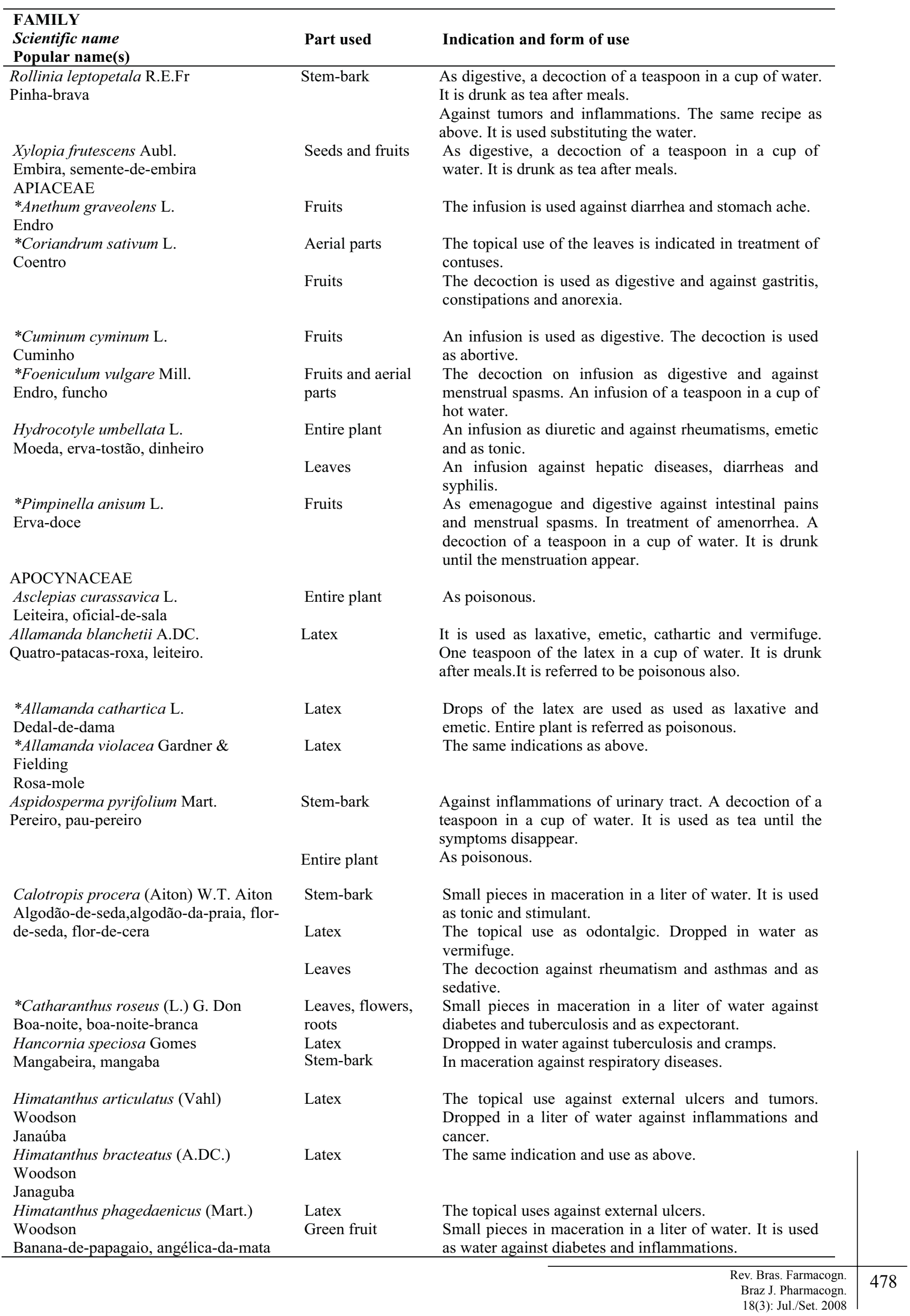




\begin{tabular}{l}
\hline FAMILY \\
Scientific name \\
Popular name(s) \\
\hline Mandevilla illustris (Vell.) Woodson \\
Purga-do-campo \\
Mandevilla tenuifolia (J.C. Mikan) \\
Woodson \\
Flor-de-santo-antonio \\
Marsdenia altissima (Jacq.) Dugand \\
Cipó-seda \\
Marsdenia molissima E.Fourn. \\
Maria-da-costa \\
*Plumeria rubra L. \\
Jasmim \\
Rauvolfia grandiflora Mart. ex A. DC. \\
Mamão-de-sapo \\
Rauvolfia ligustrina Willd. ex Roem. \& \\
Schult. \\
Arrebenta-boi \\
Schubertia grandiflora Mart. \& Zucc. \\
Maria-da-costa \\
Schubertia multiflora Mart. \\
Maria-da-costa \\
Skytanthus hancorniifolius (A. DC.) \\
Miers \\
Leiteiro \\
Tabernaemontana sp. \\
Jasmim-bravo
\end{tabular}

Jasmim-bravo

\section{ARACEAE}

Caladium bicolor (Aiton) Vent.

Tajá

Anthurium affine Schott

Folha-larga, palmeirão-bravo

Dracontium sp.

Pistia stratiotes L.

Pasta, golfo

Syagrus coronata (Mart.) Becc.

Licuri, ouricuri

ARECACEAE

Acrocomia aculeata (Jacq.)Lodd. ex

Mart.

Macaúba, macaíba

Astrocaryum vulgare Mart.

Tucum, tucumã, tucum-bravo

${ }^{*}$ Cocos nucifera $\mathrm{L}$.

Coco, coqueiro

Copernicia prunifera (Mill.) H.E.Moore Carnaubeira, carnaúba

*Elaeis guineensis Jacq.

Dendê, dendezeiro, azeite-de-dendê

Euterpe oleracea Mart.

Jussara, açaí

Mauritiella aculeata (Kunth) Burret Fruits

Buritirana

Mauritia flexuosa $\mathrm{L}$. Buriti
Part used Indication and form of use

Latex

Leaves and

flowers

Stem-bark

Roots

Latex

Stem-bark

Flowers

Entire plant

Entire plant

Tuber

Tuber

Leaves, fowers and stem bark

Stem-bark

Latex

Roots

Leaves

Flowes

Leaves

Leaves and roots

Entire plant

Bark

Fruit

Fruit

Fruit pulp

Water

Roots

Oil's fruits

Fruits

Leaves Fruits aganst liver diseases.

The decoction is vermifuge.

The syrup as expectorant.

As poisonous.

As poisonous. use against furunculous. circulatory diseases. diseases.

It is used against snake bite. dysenteries and as diuretic.

The topical use as emollient.
Some latex is dropped in a cup of water and drunk

An infusion is used against hart diseases.

A maceration against gonorrhea, asthmas and cancer. It is used to increase the fertility.

As abortive and against amenorrhea. A decoction of a handful in a liter of water. It is drunk substituting the water until the menstruation appear.

The topical use against dermatitis.

A decoction as emenagogue and abortive.

The same indication and use as above.

The infusion is used as sedative, against insomnias, hypertension, cardiac problems, asthmas and colds.

The decoction of a handful in a liter of water or in maceration in wine against syphilis.

The topical use against warts.

The decoction or syrup as expectorant.

The decoction as vermifuge and purgative. The external

A maceration is used against diabetes.

An infusion is used against cardiac problems and

It is used as decoction against rheumatisms.

The infusion is used as diuretic and against kidney

As food and source of vitamin A.

In nature as food. It is used as source of vitamin A.

As laxative. The oil extracted by heat is emollient.

It is used as tonic and hydrating against diarrheas,

A handful in a liter of water in maceration as depurative and diuretic. The topical use against external ulcers, dermatitis, rheumatism and arthritis.

The topical use on skin as emollient

The juice is drunk as general tonic.

The same indication and use as above.

Used in sweets and ice cream as source of vitamin A. 


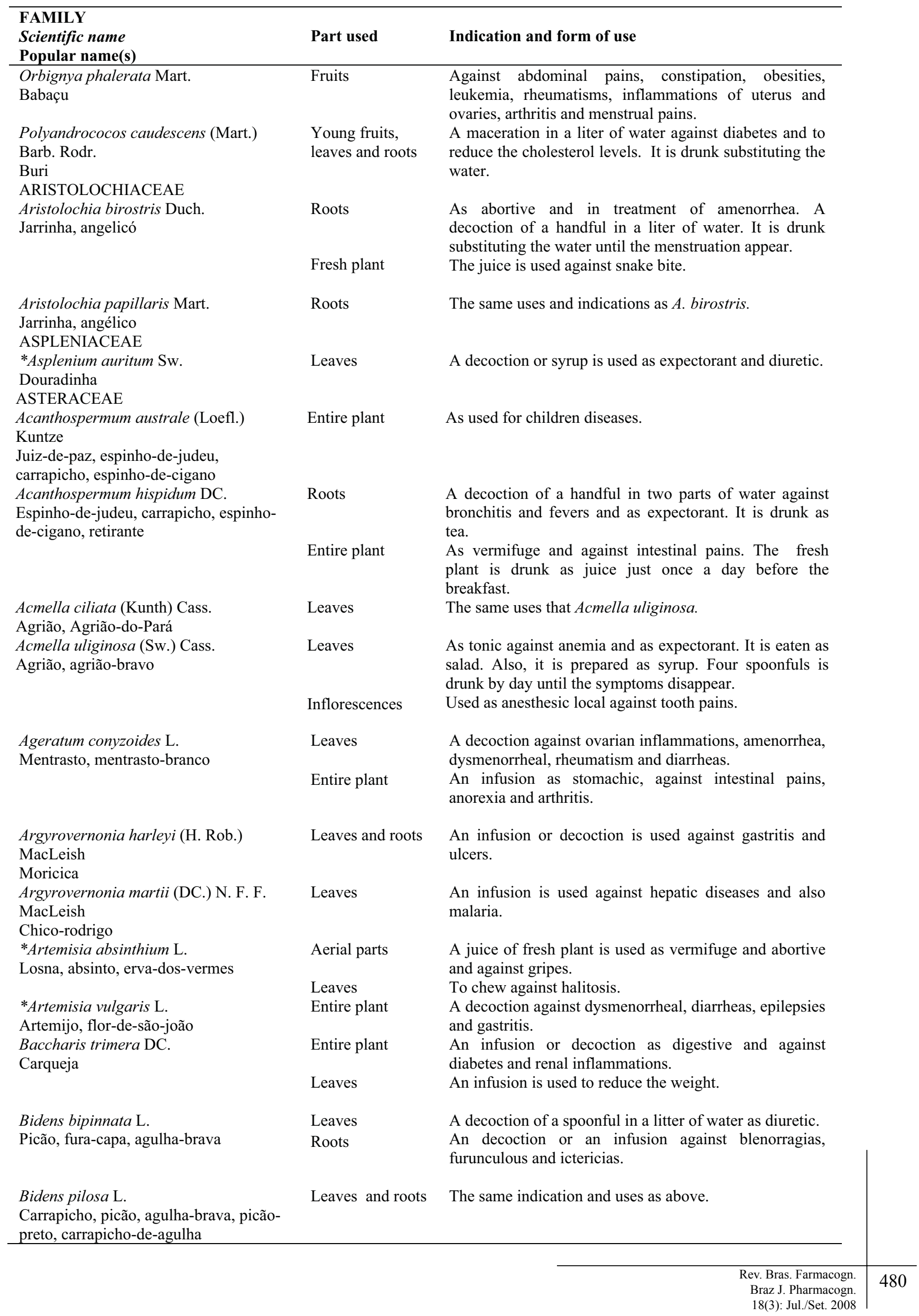




\begin{tabular}{|c|c|c|}
\hline $\begin{array}{l}\text { FAMILY } \\
\text { Scientific name } \\
\text { Popular name(s) }\end{array}$ & Part used & Indication and form of use \\
\hline Blainvillea acmella (L.) Philipson & Entire plant & It used as food in salad against anemias. \\
\hline Agrião & Flowers & $\begin{array}{l}\text { The topical use of the smashed flowers against } \\
\text { toothaches. }\end{array}$ \\
\hline $\begin{array}{l}\text { *Calendula officinalis L. } \\
\text { Calêndula }\end{array}$ & Leaves & The infusion is used against uterin inflammations. \\
\hline $\begin{array}{l}\text { Conyza bonariensis (L.) Cronquist } \\
\text { Rabo-de-raposa }\end{array}$ & Entire plant & A decoction is used against dermatitis. \\
\hline $\begin{array}{l}\text { Conocliniopsis prasiifolia (DC.) } \\
\text { R.M.King \& H.Rob. } \\
\text { Aleluia }\end{array}$ & Aerial parts & $\begin{array}{l}\text { An infusion is prepared with a handful of fresh plant in a } \\
\text { liter of hot water. It is drunk as tea against flu and colds. } \\
\text { The same preparation boiled with sugar as syrup. Three } \\
\text { spoonfuls daily until symptoms disappear. }\end{array}$ \\
\hline \multirow[t]{2}{*}{$\begin{array}{l}\text { *Dendranthema grandiflorum (Ramat.) } \\
\text { Kitam. } \\
\text { Crisântemo }\end{array}$} & Leaves & $\begin{array}{l}\text { An infusion or decoction of a handful in a liter of water } \\
\text { as stomachic. It is drunk as tea after meals, until the } \\
\text { symptoms disappear. }\end{array}$ \\
\hline & Inflorescences & A decoction or an infusion against edemas. \\
\hline \multirow[t]{2}{*}{$\begin{array}{l}\text { Eclipta prostrata }(\mathrm{L} .) \mathrm{L} . \\
\text { Agrião, perpétua-do-mato, Agrião-do- } \\
\text { brejo, erva-de-botão }\end{array}$} & Leaves & $\begin{array}{l}\text { As anti-asthmatic and against hepatitis and liver diseases. } \\
\text { An infusion or a decoction is of handful in a liter. It is } \\
\text { used as tea until symptoms disappear. }\end{array}$ \\
\hline & Inflorescences & $\begin{array}{l}\text { External ulcers. A handful is powdered and applied over } \\
\text { the affected skin. }\end{array}$ \\
\hline $\begin{array}{l}\text { Egletes viscosa (L.) Less. } \\
\text { Macela-do-campo, macela, macela-da- } \\
\text { terra }\end{array}$ & $\begin{array}{l}\text { Inflorescences and } \\
\text { leaves }\end{array}$ & $\begin{array}{l}\text { As stomachic and against diarrheas and insomnias. A } \\
\text { handful of inflorescences in a liter of water as infusion or } \\
\text { decoction. It is drunk as tea after meals until symptoms } \\
\text { disappear. }\end{array}$ \\
\hline $\begin{array}{l}\text { Emilia coccinea (Sims) G. Don } \\
\text { Pincel }\end{array}$ & Entire plant & $\begin{array}{l}\text { The infusion of a handful is used against fevers and } \\
\text { diarrheas. }\end{array}$ \\
\hline $\begin{array}{l}\text { Emilia fosbergii Nicolson } \\
\text { Pincel, serralha }\end{array}$ & $\begin{array}{l}\text { Leaves and entire } \\
\text { plant }\end{array}$ & The same use and indication as above. \\
\hline $\begin{array}{l}\text { Flaveria bidentis (L.) Kuntze } \\
\text { Contra-erva-do-peru }\end{array}$ & Inflorescence & $\begin{array}{l}\text { The decoction against verminosis. It is used before } \\
\text { breakfast. }\end{array}$ \\
\hline $\begin{array}{l}\text { Galinsoga parviflora Cav. } \\
\text { Botão-de-ouro, picão, fazendeiro }\end{array}$ & Entire plant & $\begin{array}{l}\text { Against flu and colds. An infusion of a handful in a liter } \\
\text { of water. It is drunk as tea until the symptoms disappear. }\end{array}$ \\
\hline $\begin{array}{l}\text { *Gymnanthemum amygdalinum (Delile) } \\
\text { Sch. Bip. ex Walp. } \\
\text { Alumã, boldo }\end{array}$ & Leaves & $\begin{array}{l}\text { A decoction of a handful in a liter against fevers, } \\
\text { constipation and abdominal pains. }\end{array}$ \\
\hline $\begin{array}{l}\text { Hebeclinium macrophyllum (L.) DC. } \\
\text { Desinchadeira-de-cacau }\end{array}$ & Leaves & It is used as poultice against hurt in the foot. \\
\hline \multirow[t]{2}{*}{$\begin{array}{l}\text { *Helianthus annuus L. } \\
\text { Girassol }\end{array}$} & Seeds & $\begin{array}{l}\text { In nature as food against cholesterol. An infusion of the } \\
\text { roasted and grounded seeds as "café" against fevers. }\end{array}$ \\
\hline & Leaves & The topical use as poultice against ulcers and hurts. \\
\hline $\begin{array}{l}\text { Ichthyothere terminalis (Spreng.) } \\
\text { S.F.Blake } \\
\text { Cunabi }\end{array}$ & Entire plant & It is used as poisonous. \\
\hline $\begin{array}{l}\text { *Lactuca sativa } \mathrm{L} \\
\text { Alface }\end{array}$ & Leaves & $\begin{array}{l}\text { An infusion of two leaves in a cup of water against } \\
\text { hypertension and insomnias. }\end{array}$ \\
\hline $\begin{array}{l}\text { Lepidaploa chalybaea (Mart. ex DC.) } \\
\text { H.Rob. } \\
\text { Ervanço }\end{array}$ & Leaves & $\begin{array}{l}\text { The decoction of a handful in a liter. It is used for hairs } \\
\text { washes or in baths against dandruffs. }\end{array}$ \\
\hline $\begin{array}{l}\text { Lourteigia ballotifolia (Kunth) R.M. } \\
\text { King \& H. Rob. } \\
\text { Aleluia }\end{array}$ & Entire plant & $\begin{array}{l}\text { Against flu and colds. An infusion is prepared with a } \\
\text { handful of fresh plant in a liter of hot water. It is drunk } \\
\text { as tea. The same preparation boiled with sugar as syrup. } \\
\text { Three spoonfuls daily until symptoms disappear. }\end{array}$ \\
\hline \multirow[t]{2}{*}{$\begin{array}{l}\text { *Matricaria chamomilla L. } \\
\text { Camomila }\end{array}$} & Leaves & $\begin{array}{l}\text { An internal use against coughs, colic, diarrheas, skin } \\
\text { eruptions, fevers, colds, headaches and as sedative. The } \\
\text { external use is indicated for washes against } \\
\text { conjunctivitis. }\end{array}$ \\
\hline & Flowers & $\begin{array}{l}\text { The infusion is used against nausea, vomiting, bellyache } \\
\text { (internal use) and skin diseases (external use). }\end{array}$ \\
\hline
\end{tabular}




\begin{tabular}{|c|c|c|}
\hline $\begin{array}{l}\text { FAMILY } \\
\text { Scientific name } \\
\text { Popular name(s) }\end{array}$ & Part used & Indication and form of use \\
\hline $\begin{array}{l}\text { Melampodium divaricatum (Rich.) DC. } \\
\text { Picão-da-praia }\end{array}$ & Entire plant & $\begin{array}{l}\text { A decoction or infusion as diuretic and against } \\
\text { leucorrhoea. }\end{array}$ \\
\hline $\begin{array}{l}\text { *Mikania glomerata Spreng. } \\
\text { Guaco, guaiacó }\end{array}$ & Leaves & $\begin{array}{l}\text { An infusion is used against rheumatisms and respiratory } \\
\text { diseases. As syrup is used against coughs and asthmas. } \\
\text { A decoction is used in treatement of inflammations of } \\
\text { the throat. A maceration in alcohol is used against } \\
\text { nevralgias. }\end{array}$ \\
\hline $\begin{array}{l}\text { Mikania hirsutissima DC. } \\
\text { Cipó cabeludo }\end{array}$ & Entire plant & $\begin{array}{l}\text { A decoction or infusion against diarrheas, rheumatism, } \\
\text { neuralgias, nephrites and paralysis. }\end{array}$ \\
\hline
\end{tabular}

Pectis elongata Kunth

Alecrim-do-mato, alecrim-bravo, cuminho-bravo

Cabrera

Quitoco, madrecravo

Porophylum ruderale (Jack) Cass.

Cravo-de-urubu, couvinha

Pectis linifolia L. var. linifolia

Alecrim-do-mato

Pectis oligocephala (Gardner) Sch.Bip.

Alecrim-do-mato, caminho-do-mato

Sonchus oleraceus L.

Alface-do-mato, barbalha, serralha-lisa

Sphagneticola trilobata (L.) Pruski

Mal-me-quer, camará

*Tagetes erecta

Cravo-de-defunto

Tagetes minuta $\mathrm{L}$.

Coari-bravo, cravo-de-viúva, cravo-bravo

\section{*Tanacetum vulgare $\mathrm{L}$.}

Erva-dos-vermes, ervas-de-são-marcos

Trixis divaricata (Kunth) Spreng.

Selidônea, sete-sangrias

Trixis vauthieri DC.

Sete-sangrias

Unxia suffruticosa (Baker) Stuessy

Mal-me-quer-do-sertão

Verbesina baccharifolia Mattf.

Assa-peixe

Verbesina macrophylla (Cass.) S.F.

Blake
Entire plant

Entire plant

Leaves

Leaves and entire The same indications, preparations and uses as above.

plant

Aerial parts

Inflorescence

Entire plant

Leaves

Leaves

Leaves

Leaves

Flowers and

leaves

Flowers and

leaves

Leaves

Leaves

Inflorescences

Entire plant

Entire plant

Flowers

Flowers

Flowers

Against hypotension and stomachic diseases, an infusion with two parts of water. It is drunk cold substituting the water until symptoms disappear.

As stomachic, the same recipe as above. It is drunk as tea after meals.

Against flu and colds, an infusion of a spoonful in a glass of water. It is drunk until symptoms disappear.

Against flu and colds, an infusion of a spoonful in a glass of water. It is drunk until symptoms disappear.

A decoction as stomachic and against hypertension.

The infusion as digestive and stomachic and expectorant against coughs bronchitis

It is used to facilitate the childbirth.

In uterine and testicular inflammations and against fevers. An infusion or decoction of a spoonful in a glass of water. It is drunk as tea until the symptoms disappear. An infusion as sedative. A cup is drunk at night before sleep.

As tonic, stomachic and preventive of cardiovascular diseases and against hepatitis. A decoction of a spoonful in a glass of water. It is drunk as tea until the symptoms disappear.

Against flu, colds and pneumonias. An infusion is prepared with a teaspoon in a cup of hot water. It is drunk as tea.

An infusion of a handful in a liter. It is used against asthmas.

Against evers, amenorrhea and as sedative. An infusion or decoction in two parts of water. It is drunk as tea before sleep.

As vermifuge. The same recipe as above. It is drunk only once a day.

A decoction as vermifuge.

As abortive and against amenorrhea. A decoction of a handful in a liter of water. It is drunk substituting the water until the menstruation appears. It is also used for wash the eyes against conjunctivitis.

The same uses and indications as above.

Against flu and colds. An infusion is prepared with a teaspoon in a cup of hot water. It is drunk as tea.

An infusion or decoction are used against inflammations.

The same use and indications as above. 


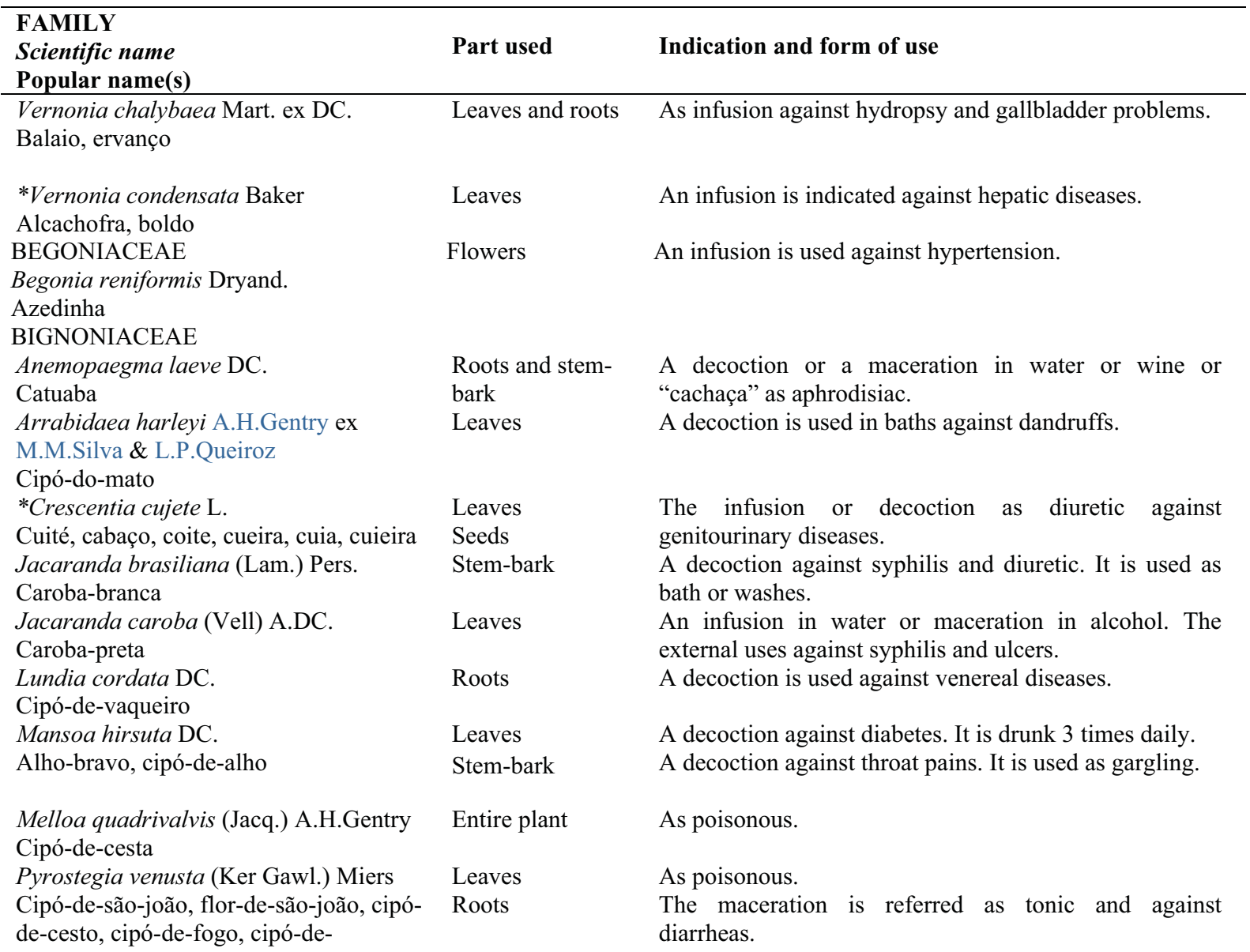

lagartixa, cipó-pé-de-lagartixa, cipó-de-

lagarto, cipó-catitu,

Tabebuia aurea (Silva-Manso) Benth. \& Stem-bark

Hook.f. ex S. Moore

Craibeira

Tabebuia avellanedae Lorentz ex Stem-bark

Griseb.

Pau-d'arco-roxo, ipê-roxo

Tabebuia chrysotricha (Mart. ex A. Stem-bark

DC.) Standl.

Ipê-amarelo, ipê-tabaco

Tabebuia impetiginosa (Mart. ex DC.) Stem-bark

Standl.

Pau-d'arco

Tabebuia serratifolia $($ Vahl) Stem-bark

Stem-bark The same indications and uses as above.

G.Nicholson

Pau d'arco amarelo

Tabebuia spongiosa Rizzini Stem-bark

Against flu and bronchitis. A decoction of a handful in a liter of water. It is drunk as tea until the symptoms disappear. In maceration it is used substituting the water against general inflammations.

Against cancer, liver diseases, inflammations of the skin, of the ear and the mucosa (gingival, throat, vagina, uterus and anus), ovaries and prostate and muscle. The maceration substituting the daily water.

A decoction is used as depurative and against eczemas, rheumatisms, dermatitis and inflammations of the oral treat.

The same indications and uses as above.

Pau-de-casca

BIXACEAE

Bixa orellana L.

Urucum, açafrão, açafroa

Aril of seeds

Roots

Leaves

BORAGINACEAE

Auxemma oncocalyx Taub. Aerial parts
The same indications and uses as Tabebuia impetiginosa.

In maceration against bronchitis, and respiratory diseases. The topical uses as insect repellent and for child illness.

As diuretic and against cardiac and vascular diseases.

A decoction is drunk against fatigues and hypertension.

An infusion or decotion against external ulcers and as cicatrizant. 


\begin{tabular}{|c|c|c|}
\hline $\begin{array}{l}\text { FAMILY } \\
\text { Scientific name } \\
\text { Popular name(s) }\end{array}$ & Part used & Indication and form of use \\
\hline \multirow{4}{*}{$\begin{array}{l}\text { Cordia globosa (Jacq.) Kunth } \\
\text { Maria-preta, bamburral, pau-pretinho } \\
\text { Cordia leucocephala } \text { Moric. } \\
\text { Moleque-duro, negro-duro }\end{array}$} & Leaves & $\begin{array}{l}\text { Against menstrual colic's. An infusion of a handful in a } \\
\text { liter. It is drunk as tea. }\end{array}$ \\
\hline & Leaves & $\begin{array}{l}\text { Against indigestions. A decoction of a handful in a glass } \\
\text { of water. It is drunk as tea. }\end{array}$ \\
\hline & Flowers & $\begin{array}{l}\text { As general tonic. As syrup prepared with a cup of flowers } \\
\text { and half liter of water. A spoonful of syrup is drunk } \\
\text { during the meals. }\end{array}$ \\
\hline & Aerial parts & Against rheumatism, arthritis and rickets. \\
\hline
\end{tabular}

Cordia multispicata Cham.

Maria-preta

Cordia polycephala (Lam.) I.M.Johnst.

Maria-preta

Grão-de-galo

Cordia trichotoma (Vell.) Arráb. ex

Steud.

Freijó, frei-jorge, cabo-de-machado

Heliotropium angiospermum Murr.

Crista-de-galo

Heliotropium indicum $\mathrm{L}$.

Fedegoso, crista-de-galo
Cordia piauiensis Fresenius

Leaves and aerial

parts

Leaves

Leaves

Leaves and stembark

Leaves and roots

Aerial parts

Roots

Leaves

Heliotropium lanceolatum Ruiz \& Pav. Sete-sangrias

Tournefortia rubicunda Salzm. ex DC. Canudeiro

BRASSICACEAE

*Brassica integrifolia (H. West.) Rupr. Seeds

Mostarda

*Brassica oleracea var. acephala DC. Leaves

Couve

Lepidium bonariense $\mathrm{L}$.

Agrião-bravo

*Nasturtium officinale $\mathrm{R}$. Br.

Agrião, agrião-verdadeiro

BROMELIACEAE

Aechmea lingulata Baker

Caroá

Ananas sativus Schult.f.

Abacaxi

Bromelia laciniosa Mart. ex Schult.f. Roots

Macambira

Bromelia plumieri (E.Morren) L.B.Sm. Fruits

Caroá, banana-de-raposa

Hohembergia sp.

Gravatá-de-folha-roxa

Tillandsia loliacea Mart. ex Schult. f. Entire plant
Leaves

Roots

Leaves

Leaves

Leaves

Flowers

Fruit

Flowers and

leaves
The same recipe and use as above.

The same recipe and use as C. leucocephala.

A decoction against rheumatism, arthritis and rickets.

Against kidney diseases, rheumatism, arthritis and rickets. A decoction of a handful in a liter of water. It is used until the symptoms disappear.

An infusion or syrup against cardiac diseases and hypertension.

As diuretic and against hepatic diseases. An infusion of a handful in $1 / 2$ liter of water. It is drunk substituting the water.

Against conjunctivitis. The same recipe as above. It used cold to wash the eyes.

Against hepatic and renal diseases and as diuretic. A maceration of a handful in a liter of "cachaça". It is drunk before meals.

A decoction or as maceration in alcohol as depurative.

A decoction is used for baths against mycosis and dermatitis.

A decoction of a teaspoon in a cup of water. It is drunk "as water" against intestinal and stomachic diseases until the symptoms disappear.

An infusion against stomachic diseases or as fresh juice. It is drunk a cup daily against osteoporosis.

It is used as salad against anemia and tuberculosis.

The same use and indications as above.

A decoction against dandruff and fall of hairs.

The juice is used as digestive and against bronchitis.

A decoction of a handful in a liter of water is used against hepatitis, intestinal diseases and as diuretic. It is drunk "as water" until the symptoms disappear.

As source of protein, dried and powdered. It is eaten mixed with the meals.

As vermifuge. It is eaten before breakfast only once.

A decoction is used against hypertension and to reduce the cholesterol levels.

A decoction is used against uterine hemorrhagies and external ulcers. 


\begin{tabular}{|c|c|}
\hline $\begin{array}{l}\text { FAMILY } \\
\text { Scientific name } \\
\text { Popular name(s) } \\
\end{array}$ & Part used \\
\hline $\begin{array}{l}\text { Tillandsia recurvata }(\mathrm{L} .) \mathrm{L} . \\
\text { Barba-de-velho }\end{array}$ & Entire plant \\
\hline $\begin{array}{l}\text { Tillandsia streptocarpa (L.) Baker } \\
\text { Gravatá-do-ar }\end{array}$ & Entire plant \\
\hline $\begin{array}{l}\text { Tillandsia usneoides (L.) L. } \\
\text { Barba-de-velho } \\
\text { BURSERACEAE }\end{array}$ & Entire plant \\
\hline $\begin{array}{l}\text { Commiphora leptophloeos } \quad \text { (Mart.) } \\
\text { J.B.Gillett }\end{array}$ & Stem-bark \\
\hline
\end{tabular}

\section{Protium heptaphyllum (Aubl.) Marchand Resin} Almécega, almiscar

Stem-bark

\author{
Protium pallidum Cuatrec. \\ Breu-branco \\ Protium tenuifolium (Engl.) Engl. \\ Almiscar \\ CARICACEAE \\ *Carica papaya L. \\ Mamão \\ Jacaratia dodecaphylla (Vell.) A. DC. \\ Jacaratiá \\ Jacaratia heptaphylla (Vell.) A.DC. \\ Jacaratiá \\ Jacaratia spinosa (Aubl.) A. DC. \\ Resin \\ Stem-bark \\ Resin \\ Stem-bark \\ Fruit \\ Leaves \\ Latex \\ Latex \\ Latex
}

Jacaratiá-de-espinho

CACTACEAE

Arrojadoa rhodantha Britton \& Rose

Rabo-de-raposa

Cereus hildmannianus K. Schum.

Mandacaru-de-três-quinas

Cereus jamacaru DC.

Mandacaru

Cladodes and

roots

Cladodes

Roots

Stem pulp

Harrisia adscendens (Gürke) Britton \& Roots

Rose

Rabo-de-raposa

Melocactus bahiensis (Britton \& Rose) Stem pulp

Luetzelb.

Coroa-de-frade

Melocactus macrodiscus Werderm. Stem pulp

Coroa-de-frade

Melocactus zehntneri (Britton \& Rose) Stem pulp

Luetzelb.

Coroa-de-frade, cabeça-de-frade

Opuntia ficus-indica Mill.

Palma-de-gato, palmatória

Pereskia aculeata Mill.

Carne-de-pobre

\section{Indication and form of use}

Against rheumatism, ulcers and hemorrhoids. A decoction of a small plant in a liter of water. It is used as tea once a day until the symptoms disappear.

As purgative, laxative and emetic. A decoction of $1 / 4$ of a plant in a liter of water. It is used as tea after meal until the symptoms disappear.

A handful in a cup of water is used against hemorrhoids.

In treatment of flu, coughs, bronchitis, treat urinary and liver diseases. A decoction of a handful in a liter of water and made with sugar as syrup. A spoonful is drunk 5-6 times a day. The external use against ulcers in washes or baths against vaginal ulcers.

It is mixed and grounded with tobacco leaves. It is used as "rapé" (snuff) against sinusitis.

As syrup or decoction against coughs and bronchitis.

The same indications and uses as above.

The same uses and indications as $P$. heptaphyllum.

It is used "in nature" as digestive, laxative and against high blood pressure.

An infusion is used as digestive

It is dropped in a cup of water and drunk as purgative and against intestinal worms.

The same uses and recipe as above.

The same uses and recipe as above.

A decoction or maceration is used against cardiac diseases and gastritis.

The pulp is used against renal lithiasis.

Against respiratory and renal diseases, as diuretic. An infusion of a handful in a liter of water. It is drunk substituting the water until the symptoms disappear.

Against stomachic ulcers. It is mashed with sugar. A spoonful is drunk three times.

An infusion against amenorrhea and as diuretic and antiinflammatory.

It is used against coughs and bronchitis.

The same indication and uses as above.

Treatment of bronchitis and coughs and in physical debility. As juice. It is drunk before meals.

Cladodes The topic use of the pulp is indicated against vaginal and urinary inflammations, stomachache pains, rheumatisms, constipations and dysenteries.

The pulp is used as emollient. 







\begin{tabular}{|c|c|c|}
\hline $\begin{array}{l}\text { FAMILY } \\
\text { Scientific name } \\
\text { Popular name(s) }\end{array}$ & Part used & Indication and form of use \\
\hline $\begin{array}{l}\text { Cecropia obtusa Trécul } \\
\text { Imbaúba }\end{array}$ & Leaves & $\begin{array}{l}\text { A maceration of a handful in a litter of water is indicated } \\
\text { against diabetes. It is drunk as substituting water. }\end{array}$ \\
\hline $\begin{array}{l}\text { Cecropia palmata Willd. } \\
\text { Torém, imbaúba }\end{array}$ & Leaves & The infusion as stimulant, tonic and as diuretic. \\
\hline $\begin{array}{l}\text { Cecropia peltata } \mathrm{L} \text {. } \\
\text { Imbaúba, simbaúba } \\
\text { CELASTRACEAE }\end{array}$ & Leaves & The decoction against hart diseases and diabetes. \\
\hline Maytenus obtusifolia Mart. & Leaves & A decoction against general inflammations and cancer. \\
\hline Carrancudo & Stem-bark & $\begin{array}{l}\text { Grounded as powder it is used against external ulcers on } \\
\text { the skin. }\end{array}$ \\
\hline $\begin{array}{l}\text { Maytenus rigida Mart. } \\
\text { Bom-nome }\end{array}$ & Stem-bark & $\begin{array}{l}\text { Against infections and inflammations of ovaries and } \\
\text { kidneys and cancer. A decoction or infusion or maceration } \\
\text { of a handful in a liter of water. It is drunk substituting the } \\
\text { water. Against external cancer and ulcers. A decoction is } \\
\text { prepared and used to wash the external affections. }\end{array}$ \\
\hline
\end{tabular}

\section{CHENOPODIACEAE}

*Beta vulgaris L.

Beterraba

Chenopodium ambrosioides $\mathrm{L}$.

Mastruço

CHRYSOBALANACEAE

Chysobalanus icaco L.

Guajerú, guajiru

Licania rigida Benth.

Oiticica

\section{CLUSIACEAE}

Garcinia madruno (Kunth) Hammel

Bacuri

Platonia insignis Mart.

Bacuripari, Bacuri

Rheedia macrophylla (Mart.) Planch. \& Resin

Triana

Bacurí, Bacuriparí

Vismia guianensis (Aubl.) Pers.

Lacre

Vismia reichardtiana (Kuntze) Ewan

Lacre, lacre vermelho

COMBRETACEAE

Buchenavia tetraphylla (Aubl.)

R.A.Howard

Caicaró

Combretum glaucocarpum Mart.

Sipaúba

Combretum lanceolatum Pohl ex Eichler Stem-bark

Mofumbo-do-rio, mofumbo

Combretum leprosum Mart.

Mofumbo, mofumbo-branco, pente-de-

macaco

*Terminalia catappa L.

Castanhola, amendoeira

COMMELINACEAE

Commelina erecta $\mathrm{L}$.

Erva-de-santa-luzia

Commelina nudiflora $\mathrm{L}$.

Marianinha

Tradescantia zebrina Heynh. Marianinha, Zebrina
Tuber

Entire plant

Roots

Stem-bark

Leaves

Fruit

Seeds

Stem-bark

Latex

Stem-bark

Entire plant

Stem-bark and

leaves

Leaves

Fruits

Inflorescences

Inflorescences

Entire plant
It is used as syrup against flu and as expectorant.

As vermifuge, stomachic and expectoran. A juice of entire plant is extracted with milk. It is drunk before breakfast.

The maceration against diabetes and inflammations. It is drunk daily as water.

The decoction against diarrheas.

Against diabetes. A handful in decoction in a liter of water. It is drunk substituting the water until the symptoms disappear.

As juice against anemias.

The seed oil's against eczemas and herpes. The decoction against diarrheas.

Against skin diseases and wound.

The infusion or maceration as laxative and against dermatitis.

The topical use against furunculous. It is dropped in water and drunk as purgative.

An infusion as digestive. It is drunk after meals.

As poisonous.

The same indications and uses as above.

As expectorant and against coughs and diarrheas. A decoction or syrup of a handful in $1 / 2$ liter of water. It is drunk as tea or as syrup four times a day.

The same indications and uses as above.

The nut is used as tonic against general weakness.

Against conjunctivitis. The liquid from the floral spathes is dropped in the infected eyes.

The same indication and uses as above.

The infusion is used as ophthalmic. It is dropped in infected eyes. 


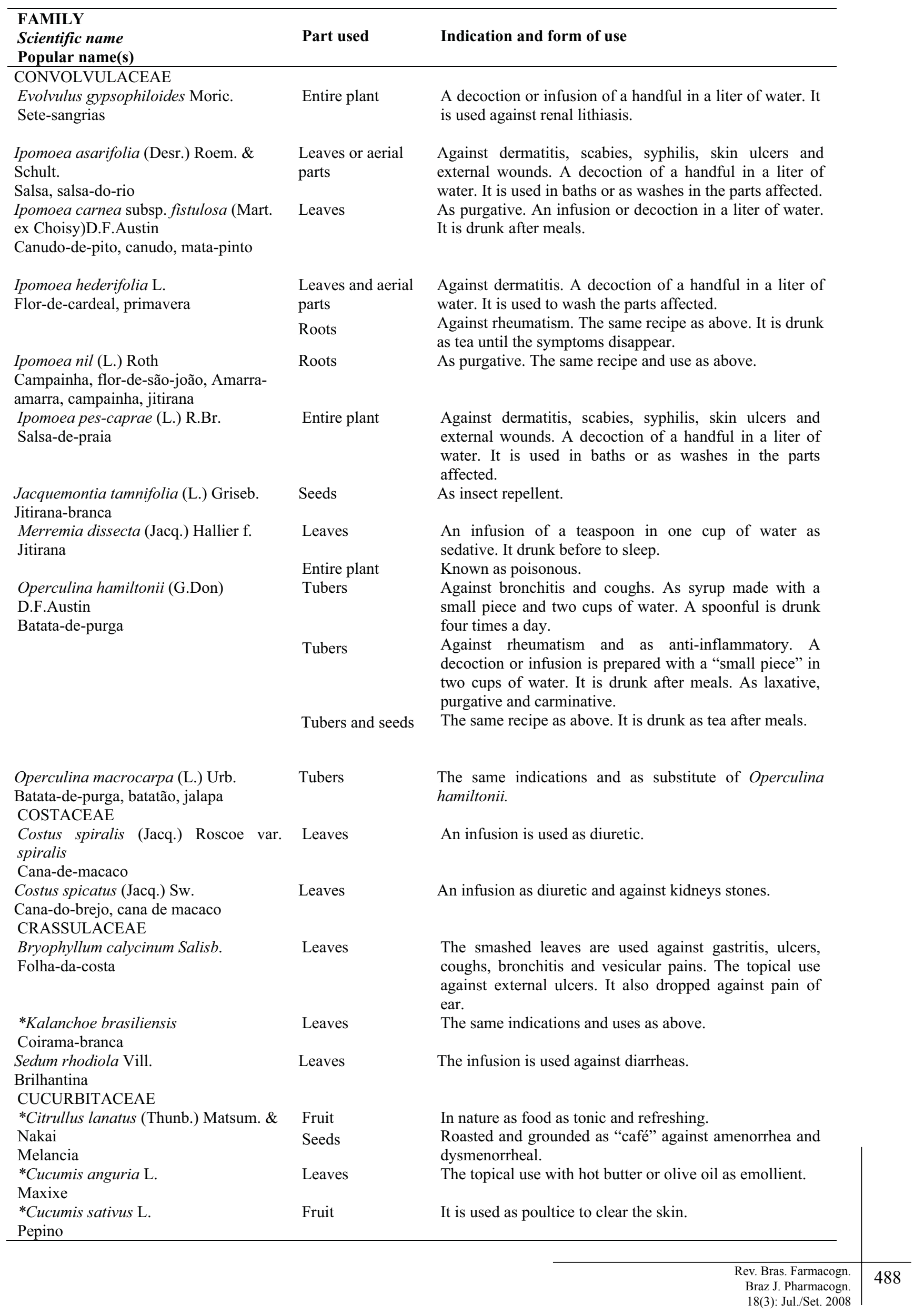




\begin{tabular}{|c|c|c|}
\hline $\begin{array}{l}\text { FAMILY } \\
\text { Scientific name } \\
\text { Popular name(s) }\end{array}$ & Part used & Indication and form of use \\
\hline Cucurbita lagenaria $\mathrm{L}$. & Leaves & Against circulatory problems. \\
\hline Cabaça & Fruit & Hidropisias. \\
\hline $\begin{array}{l}\text { *Cucurbita pepo } \mathrm{L} . \\
\text { Abóbora, jerimum }\end{array}$ & Seeds & $\begin{array}{l}\text { Grounded with milk. It is drunk before the breakfast } \\
\text { against verminosis. }\end{array}$ \\
\hline $\begin{array}{l}\text { *Lagenaria siceraria (Molina) Standl. } \\
\text { Cabaça }\end{array}$ & Fruit pulp & The pulp is drunk against hidropisias. \\
\hline $\begin{array}{l}\text { Luffa cylindrica } \text { M. Roem. } \\
\text { Bucha }\end{array}$ & Seeds & As vermifuge and against constipation. \\
\hline $\begin{array}{l}\text { Luffa operculata (L.) Cogn. } \\
\text { Cabacinha, buchinha }\end{array}$ & Fruits & $\begin{array}{l}\text { Against amenorrhea. A decoction of } 1 / 4 \text { of the fruit in a } \\
\text { cup of water. It is drunk only once. Against sinusitis, the } \\
\text { same recipe as above is dropped into the noses. }\end{array}$ \\
\hline $\begin{array}{l}\text { Momordica charantia } \text { L. } \\
\text { Melão-de-sabiá, melão-de-são-caetano, } \\
\text { galinha-de-melão }\end{array}$ & Fruits & $\begin{array}{l}\text { As anti-diabetic and vermifuge and against rheumatisms } \\
\text { and diarrheas. A decoction of a handful in a liter of } \\
\text { water. It is drunk as tea, until the symptoms disappear. } \\
\text { Against dandruff. A decoction of a handful in a liter of } \\
\text { water. It is used to wash the hair until dandruff disappear. }\end{array}$ \\
\hline $\begin{array}{l}\text { *Sechium edule (Jacq.) Sw. } \\
\text { Chuchu }\end{array}$ & Fruit & $\begin{array}{l}\text { As juice mixed with orange juice is drunk against } \\
\text { hypertension. }\end{array}$ \\
\hline $\begin{array}{l}\text { Wilbrandia verticillata (Vell.) Cogn. } \\
\text { Cabeça-de-negro }\end{array}$ & $\begin{array}{l}\text { Leaves } \\
\text { Tuber }\end{array}$ & $\begin{array}{l}\text { An infusion as hypotensive. } \\
\text { As decoction, syrup or as maceration of a handful in a } \\
\text { liter. It is drunk as purgative and depurative against } \\
\text { syphilis and furunculosis. }\end{array}$ \\
\hline
\end{tabular}

CYATHEACEAE

Cyathea microdonta (Desv.) Domin Fronds

An infusion is indicated against cholics and as digestive.

Pau-cardoso

CYPERACEAE

Cyperus esculentus L.

Junça

Rhynchospora nervosa (Vahl) Boeck. Entire plant

Capim-estrela

DILLENIACEAE

Curatella americana $\mathrm{L}$

Sambaiba, lixeira

DIOSCOREACEAE

Dioscorea sincorensis Kunth Leaves and

Salgueiro

EQUISETACEAE

*Equisetum sp.

Cavalinha

ERYTHROXYLACEAE

Erythroxylum pungens O. E. Schulz,

Rompe-gibão, catuaba

Erythroxylum revolutum Mart.

Araçá-bravo

flowers

Aerial parts

The decoction is used as digestive.

against inflammations and venereal diseases.

Stem-bark

As a decoction against inflammations.

\section{EUPHORBIACEAE}

Acalypha multicaulis Müll. Arg.

Canela-de-nambu

Aleurites moluccanus (L.) Willd.

Nogueira, nogueira-da-india, nogueira-

de-bancul, Nogueira-de-iguape.

Chamaesyce hyssopifolia (L.) Small

Porca-parideira

Cnidoscolus infestus Pax. \& K.Hoffm.

Urtiga-de-boi

Stem-bark

Leaves and

flowers

The decoction is used against renal diseases, anemias, throat inflammation, bloodness and diarrheas.

The decoction is used against anemias and indigestion.

Cnidoscolus quercifolius (Müll.Arg.) Stem-bark

Pax \& K.Hoffm.

Favela, faveleiro, queimadeira

Roots

Leaves, flowers

and roots

Stem-bark

Latex
As maceration in water or cachaça as aphrodisiac. It is drunk before meals.

A decoction in water or a maceration in "cachaça" is used as aphrodisiac and also indicated against cardiac diseases and hypertension.

The decoction is used against stroke, hemorrhagies, tooth pains and general inflammation.

Against urinary and ovarian inflammations. A handful as decoction in a liter of water. It is drunk substituting the water until the symptoms disappear.

Decoction is used against flu, coughs problems, to expel placenta.

As anti-inflammatory of the ovaries and prostates. A decoction of a handful in a liter of water. It is drunk substituting the water until the symptoms disappear.

As anti-inflammatory of the ovaries and prostates. A decoction of a handful in a liter of water. It is drunk substituting the water until the symptoms disappear. Against external ulcers. 





FAMILY

Scientific name

Popular name(s)

Manihot glaziovii Müll. Arg.

Maniçoba

*Manihot esculenta Crantz

Aipim, macacheira, mandioca, mandioca-branca, mandioca-roxa, maniva

Maprounea guianensis Aubl.

Phyllanthus claussenii Müll. Arg.

Quebra-pedra-da-mata

Phyllanthus niruri L.

Quebra-pedra

Ricinus communis L.

Rícino, mamona

Sapium argutum (Müll. Arg.) Huber

Pau-de-leite, pau-de-candeia, burra-

leiteira

Sapium sellowianum (Müll. Arg.)

Klotzsch ex Baill.

Burra-leiteira

Sebastiania brasiliensis Spreng.

Purga-de-leite

Sebastiania jacobinensis Müll. Arg. Leiteiro

Sebastiania macrocarpa Müll. Arg. Purga-de-leite, brandão

Tragia volubilis L.

Urtiga-de-rama, cansanção

FABACEAE-CAESALPINIOIDEAE

Bauhinia cheilantha (Bong.)Steud

Mororó, pata-de-vaca

Bauhinia forficata Link

Mororó, pata-de-vaca

Bauhinia longifolia D.Dietr.

Unha-de-vaca, pata-de-vaca

Bauhinia macrostachya Benth.

Pata de vaca, pé-de-boi, mororó-da-

catinga

*Bauhinia monandra Kurz

Mororó

Bauhinia pentandra (Bong.)Vogel ex

Steud

Mororó-de-espinho

Bauhinia pulchella Benth.

Mororó-de-rama

*Bauhinia purpurea Wall.

Pata de vaca

Caesalpinia bracteosa Tul.

Catingueira, pau-de-rato, pau-santo

Caesalpinia echinata Lam.

Pau-brasil

Caesalpinia ferrea Mart.

Pau-ferro, jucá

Caesalpinia microphylla Mart. ex

G.Don

Arranca-estribo

Caesalpinia pulcherrima (L.) Sw. Maravilha

Part used Indication and form of use

Leaves

Starch

Stem-root

Aerial parts

Entire plant

Seeds

Stem-bark

Stem-bark

Stem-bark

Latex

Stem-bark

Stem-bark

Entire plant

Leaves and stem-

bark

Leaves

Leaves

Leaves

Stem-bark

Stem-bark

Stem-bark

Leaves

Fruits and stem-

bark

Stem-bark

Stem-bark

Epicarp

Stem-bark
The infusion of a small piece against anorexia. As poisonous.

A decoction is used against renal diseases.

A decoction or infusion as diuretic and against kidney stones.

The oil from seeds is used as purgative.

A decoction as abortive and purgative. The external use against ulcers.

The same use and recipe as above.

A decoction is drunk against amenorrhea, leucorrhoea and as purgative and diuretic. The topical use against dermatitis, eczema, hidropsias and syphilis.

The same indications as above.

A decoction is used as purgative and against hidropisias and syphilis. An infusion is used against dermatitis, eczemas and leucorrhoeas.

The sames indications and uses as above.

The decoction is drunk as diuretic.

As a tonic and depurative and against diabetes. An infusion or decoction of a handful in a liter of water. It is drunk during the meals until the symptoms disappear.

The same uses and indications as above.

The same uses and indications as $B$. cheilanta.

Against diabetes. An infusion or a decoction of a handful in a liter of water. It is drunk before meals.

The same uses and indications as $B$. cheilanta.

The same uses and indications as $B$. cheilanta.

The same uses and indications as $B$. cheilanta.

The infusion is used against diabetes.

The decoction of a handful in a liter of water as tonic.

The decoction against external ulcers. It is drunk as tonic.

A decoction or as "garrafada" against anemia, diarrheas and dysenteries.

The syrup is drunk against coughs and anemias.

The decoction is drunk as digestive and sedative.

Leaves

The decoction is used against gastritis. 


\begin{tabular}{ll}
\hline FAMILY & Part use \\
$\begin{array}{l}\text { Scientific name } \\
\text { Popular name(s) }\end{array}$ & \\
\hline $\begin{array}{l}\text { Caesalpinia pyramidalis } \text { Tul. } \\
\text { Catingueira }\end{array}$ & Stem-bark
\end{tabular}

Cenostigma gardnerianum Tul.

Canela-de-velho

Chamaecrista flexuosa (L.) Greene

Capim-de-cobra

Copaifera langsdorffii Desf.

Pau-dóia

Copaifera multijuga Hayne

Copaíba

Copaifera reticulata Ducke

Copaíba

Dimorphandra gardneriana Tul.

Fava d'anta

Diptychandra aurantiaca subsp. Stem-bark epunctata (Tul.) Lima, Carvalho \& Costa ex G.P. Lewis

Hymenaea courbaril L.

Jatobá

Hymenaea intermedia Ducke

Jutaí

Hymenaea martiana Hayne

Jatobá

Hymenaea oblongifolia Huber

Jatobá

Hymenaea parvifolia Huber

Jutaí do campo

Hymenaea stigonocarpa Mart. ex

Hayne

Jatobá, jatobá-da-casca-fina

Macroptilium lathyroides (L.) Urb.

Orelha-de-rato

Parkinsonia aculeata $L$.

Turco, tangerim

Peltogyne pauciflora Benth.

Pau-de-morro, jatobá

Senna alata (L.) Roxb.

Mangerioba-grande

Senna alexandrina Mill.

Sena

Senna georgica H.S. Irwin \& Barneby

Lava-pratos

Senna martiana (Benth.) H.S.Irwin \&

Barneby

Canafístula, café-bravo

Senna obtusifolia (L.) H.S.Irwin \& Leaves

Barneby

Mata-pasto, fedegoso

\section{Indication and form of use}

As aphrodisiac. A maceration of a handful in a liter of wine or "cachaça". It is drunk before the meals two times a day. Against dysenteries, diarrheas and stomachache. A decoction of one part in two parts of water. It is drunk as tea until the symptoms disappear. As an expectorant and used against bronchitis, coughs and respiratory infections. A decoction with sugar as syrup. A spoonful of the syrup is drunk four to five times a day.
Stem-bark or

resin

Roots

Stem-bark

Fruit oil

Entire plant

Fruits

Stem-bark

Resin

Epicarp

Stem-bark and epicarp

Stem-bark and epicarp

Stem-bark and epicarp

Stem-bark and epicarp

Stem-bark and epicarp

Leaves

Seeds

Leaves

Leaves

Leaves

Leaves

Leaves A decoction is drunk as anti-rheumatic.

The decoction against kidney infections.

The decoction is used against general pains.

The oil extracted from the plant is used against cancer and general inflammations.

The same uses and indications as above.

A decoction against hemorrhoids, varicose veins, haematom and vascular diseases.

A decoction is drunk as purgative.

A decoction or as syrup. It is drunk against coughs and anemia.

It is used against sinusitis and abdominal spasms.

The syrup is drunk as tonic against anemia.

The same uses and indications as above.

The same uses and indications as H. courbaril.

The same uses and indications as $H$. courbaril.

The same uses and indications as $H$. courbaril.

The same uses and indications as H. courbaril.

A decoction is used against hemorrhagies and stroke.

Against fevers and malaria. The seeds are roasted, powdered, and prepared as coffee and drunk as tea until the symptoms disappear. As antiepileptic and febrifuge. As infusion or decoction of a handful in a liter of water. It is drunk as tea. Against snakebite. A decoction of a handful in a liter of water. It is drunk substituting the water.

A decoction is used against flatulence and as sedative.

The decoction against scabies, herpes and dermatitis.

The infusion is used as laxative.

The same use as above.

An infusion of a handful in two cups of water as laxative and abortive. It is drunk until the symptoms disappear.

The infusion is indicated as abortive and laxative. Against amenorrhea and rheumatism also. An infusion of a teaspoon in a cup of water as sedative. 


\section{FAMILY}

Scientific name

Popular name(s)

Fedegoso, mata-pasto

Senna spectabilis var. excelsa

(Schrad.)H.S.Irwin \& Barneby

Canafístula
Senna occidentalis (L.)Link

\section{Part used}

Leaves

Seeds

Stem-bark

Leaves

Roots

Seeds

Senna splendida (Vogel) H.S. Irwin \& Leaves

Barneby

Feijão-brabo, canafístula

Senna uniflora (Mill.) H.S.Irwin \& Leaves

Barneby

Mata-pasto-cabeludo

Senna tora (L.) Roxb.

Mata-pasto

Senna trachypus (Mart. ex Benth.) H.S. Stem-bark

Irwin \& Barneby

Quebra machado

Senna velutina (Vogel) H.S.Irwin \&

Barneby

São-joão

*Tamarindus indica $\mathrm{L}$.

Tamarindo

\section{FABACEAE-FABOIDEAE}

Amburana cearensis (Allemão)

A.C.Sm.

Amburana, cumarú, umburana-decheiro, amburana, umburana

Leaves

Seeds

Bark

Leaves

Fruit

Stem-bark

Stem-bark
Bowdichia virgilioides Kunth

Sucupira-preta

*Cajanus cajan (L.) Millsp.

Guandu, feijão-guandu, mangalo

Centrosema brasiliana (L.) Benth.

Abre-caminho

Clitoria ternatea $\mathrm{L}$.

Abre-caminho, piriquitinho

Crotalaria retusa $\mathrm{L}$.

Guizo-de-cascavel

Dioclea grandiflora Mart. ex Benth.

Mucunã, parreira-brava

\section{Indication and form of use}

A decoction of a spoonful in a cup of water is used as a general tonic.

Roasted and powdered is prepared as coffee. It is drunk as tonic for memory. A cup is drunk after meals until the symptoms disappear.

Against flu and colds. A decoction of a spoonful in a cup of water. It is drunk as tea or as syrup four times a day.

As a laxative and purgative. The same recipe as above. It is drunk as tea.

Against amenorrhea. The same recipe and use as above. Against anemias. It is Roasted and powdered and is prepared as coffee. A cup is drunk after meals until the symptoms disappear.

The decoction against kidneys diseases.

An infusion is indicated against intestinal diseases and as laxative.

An infusion is used as purgative and as sedative.

The decoction is used against liver diseases.

The external use of a decoction against dermatitis.

The decoction of a handful in a liter. It is used against toothaches and kidney diseases.

The juice or pulp is used as laxative. Stem-bark or seeds

Stem-bark

In treatment of flu, coughs and bronchitis. A decoction of a handful in two parts of water made as syrup. A spoonful of it is drunk four to six times a day.

As tonic in anorexia. The same recipe and use as above. Against external ulcers. The dried stem-bark is grounded as powder. It is applied on the part affected until complete scar disappears.

As adjuvant in treatment of sinusitis. The same recipe as above. It is used for nasal inhalation. In the treatment of urinary infections. A maceration of a handful in a liter of water. It is drunk substituting the water until the symptoms disappear.

Stem-bark

Leaves

Entire plant

Roots

Seeds

Entire plant

Roots
A decoction against vaginal ulcers. It is used in baths and washes.

A decoction is drunk against rheumatism.

As vermifuge. A decoction of a handful in a liter of water. It is drunk as tea until the symptoms disappear. An infusion as purgative and vermifuge Against vomits and amenorrheas.

As poisonous.

Against prostate inflammations. A handful in decoction in a liter of water. It is drunk substituting the water until the symptoms disappear. 


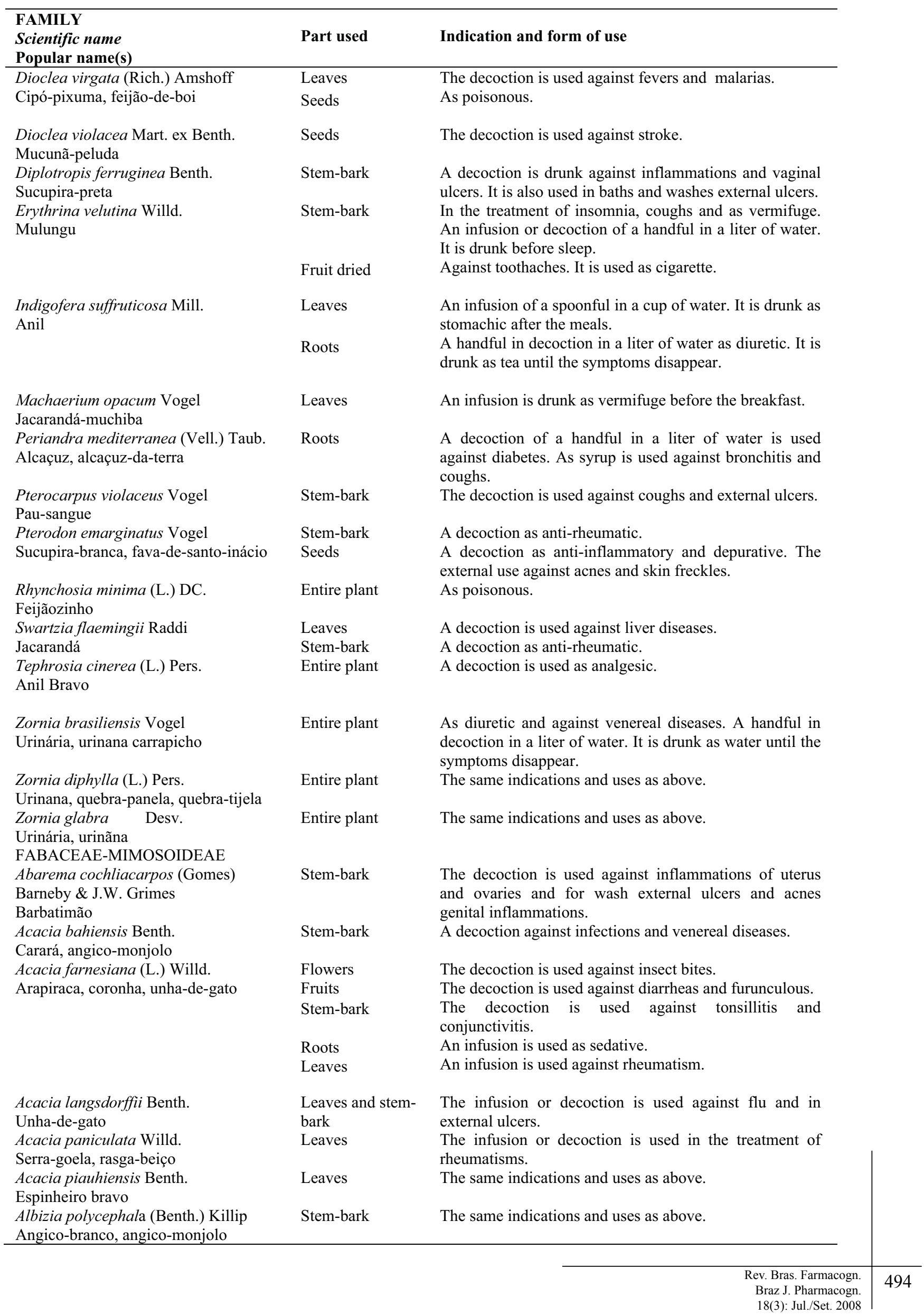




\section{FAMILY}

Scientific name

Popular name(s)

Anadenanthera colubrina var. cebil

(Griseb.)Altschul

Angico, angico-vermelho, angico-de-

casca

Calliandra depauperata Benth.

Carqueija

Chloroleucon dumosum (Benth.)

G.P.Lewis

Jurema-branca

Chloroleucon foliolosum (Benth.)

G.P.Lewis

Jurema-branca, treadina

Enterolobium contortisiliquum

(Vell.)Morong

Timbaúba, orelha-de-negro, tambor

Inga alba (Sw.) Willd

Ingá-xixi

*Leucaena leucocephala (Lam.) de Wit

Linhaça

Mimosa acutistipula (Mart.) Benth.

Jurema-preta

Mimosa arenosa (Willd.) Poir.

Calumbi

Mimosa caesalpiniifolia Benth.

Sabiá

Mimosa candollei R.Grether

Malicinha-da-roça

Mimosa ophthalmocentra Mart. ex

Benth.

Jurema-preta

Mimosa tenuiflora (Willd.) Poir.

Jurema, jurema-preta

Mimosa verrucosa Benth.

Jurema

Piptadenia obliqua (Pers.) J.F.Macbr. Angico-de-bezerro

Piptadenia viridiflora (Kunth) Benth.

Jacurutu, espinheiro-preto

*Prosopis juliflora (Sw.) DC.

Albarobo, Algaroba, Algarobeira,

Algarobia

Pithecellobium diversifolium Benth. $\quad$ Stem-bark

Carcarozeiro

Stryphnodendron adstringens (Mart.) Stem-bark

Coville

Barbatimão, barbadenã

\section{Part used Indication and form of use}

Stem-bark

Fruits

Leaves, stem-

bark and

roots

Stem-bark

Stem-bark

Stem-bark

Fruits

Stem-bark

Oil of seeds

Stem-bark

Leaves

Stem-bark

Roots

Stem-bark

Stem-bark

Leaves

Stem-bark

Stem-bark

Stem-bark

Leaves symptoms disappear. symptoms disappear. infested. emetic. disappear. bruises. symptoms disappear. washes. disappear. toothaches. conjunctivitis. inflammations
Against coughs, whooping coughs and bronchitis. A maceration of a handful in a liter of wine or "cachaça". It is drunk until the is drunk three times a day until the

As narcotic and poison. In maceration or infusion of a handful in a liter of water. It drunk before sleep.

A decoction against diabetes. It is drunk substituting the water. As gargling is used against infections of throat.

A decoction of a small piece in a cup of water. It is drunk against fevers and anemia, until the symptoms disappear.

A decoction of a small piece in a cup of water. It is drunk against fevers, hemorrhages and anemia, until the

As anti-inflammatory. A decoction of a small piece in a cup of water. It is drunk until the symptoms disappear.

Against scabies. It is used as soap to wash the area

A decoction of a handful in a liter of water. It is drunk as

As poultice against external inflammations.

As sedative and against diarrhea. A decoction of a small piece in a cup of water. It is drunk until the symptoms

A decoction as anti-rheumatic and as poultice against

As expectorant and against respiratory diseases. As syrup of a small piece in a cup of water and sugar. It is drunk until the symptoms disappear.

As diuretic. A decoction of a small piece in a cup of water. It is drunk until the symptoms disappear.

Against bronchitis and coughs. A decoction of a handful in a liter of water or as syrup. It is drunk until the

Against bronchitis and coughs. The same use as above. Against external ulcers. A decoction for baths and

As sedative and narcotic. A decoction of a handful in a liter of water or as syrup. It is drunk until the symptoms

As haemostatic and digestive. A decoction of a handful in a liter of water. It is drunk until the symptoms disappear. The external use against furunculous.

The decoction against asthmas, intestinal spasms and

An infusion, decoction and syrup. It is used against asthma and bronchitis. Dropped into the eyes against

The decoction is used against diabetes and bronchitis. The external use as indicated in baths against uterus

A decoction is used against diarrhea and hemorragies. 







\section{FAMILY}

Scientific name

Popular name(s)

Leucas martinicensis (Jacq.) R. Br.

Cordão-de-frade, cordão-de-são-

francisco

\author{
Marsypianthes chamaedrys \\ (Vahl)Kuntze
}

Hortelã-do-mato, bentônica-brava

* Mentha arvensis L.

Hortelã-vick, hortelã-do-Brasil

* Mentha crispa L.

Hortelã-rasteira

* Mentha piperita L.

Hortelã-pimenta, alevante

* Mentha pulegium L.

Poejo, melissa

* Mentha $x$ villosa-nervata Opiz

Hortelã-da-folha-miúda

Ocimum americanum $\mathrm{L}$.

Remédio-de-vaqueiro

*Ocimum basilicum L.

Manjericão, manjericão-menino

Ocimum campechianum Mill.

Alfavaca, alfavaca-de-galinha

Ocimum fluminense Vell.

Alfavaca

* Ocimum gratissimum L.

Louro, alfavaca, alfavaca-de-cheiro, quioiô-branco, tioiô, quioiô

*Plectranthus amboinicus (Lour.)

Spreng.

Hortelã graúda, malva

*Plectranthus unguentarius Codd

Hortelã-graúda

Rhaphiodon echinus Schauer

Flor-de-urubu

*Rosmarinus officinalis L.

Alecrim, alecrim-verdadeiro

\section{LAURACEAE}

*Cinnamomum zeylanicum Blume

Canela

**Laurus nobilis L.

Louro

Nectandra puberula (Schott) Nees

Canela

*Persea americana Mill.

Abacate

LECYTHIDACEAE

Eschweilera ovata (Cambess.) Miers

Biriba, biriba-branca, biriba-preta,

ibiraba, imbiriba, sapucaínha,

Lecythis pisonis Cambess

Sapucaia, cumbuca-de-macaco

\section{Part used Indication and form of use}

Leaves

Against kidney disorders and inflammations. A decoction of a handful in a liter of water. It is drunk as tea until the symptoms disappear. Against rheumatism.

Aerial parts

Entire plant

Leaves

Leaves

Leaves

Leaves

Leaves and Entire A syrup is used against colds and flu.

plant

Leaves

Leaves

Leaves

Leaves

Leaves and seeds

Leaves

Leaves and aerial parts

Leaves

Leaves and roots

Leaves or entire plant

Stem-bark or leaves

Leaves

Bark and leaves

Leaves

Seeds

Oil's seeds

Seeds The same recipe as above. It is used as washes for the affected areas.

As carminative and digestive. An infusion of a handful in a cup of water. It is drunk as tea after the meals.

As febrifuge and against bronchitis and coughs. The same recipe as above or as syrup with honey. A teaspoon is used four times for day.

The infusion is used as digestive and against vomits. The external use is indicated against dermatitis.

The same indication as above. As carminative, stomachic and tonic.

A decoction is used against general inflammations, headaches, thrombosis, ulcers and as antiseptic.

The infusion as sedative and stimulant of the gastric functions.

As syrup or juice against amoebas and verminoses. An infusion against bronchitis and as expectorant.

An infusion or as syrup against asthmas, fevers, coughs, flu, bronchitis and as stomachic and digestive.

The same uses and indications as $O$. americanum.

The same uses and indications as above.

The same uses and indications as above.

As emenagogue, stomachic, digestive, purgative and expectorant. It is used as decoction or syrup.

The juice is used against otalgias, coughs, bronchitis, tonsillitis, pneumonias, flu, menstrual disturbances, dysphonias, stomachic, helminthiasis and as expectorant. An infusion or as syrup as emenagogue, stomachic, digestive, purgative and expectorant.

A decoction is used against uterine inflammations.

As stomachic, digestive and anti-hypertensive. A handful in a cup of water. It is drunk as tea after the meals.

As stomachic, digestive and hypertensive. A decoction of a teaspoon in a cup of water. It is drunk as tea after the meals.

The infusion is used against intestinal and hepatic diseases and in rheumatism pains.

The infusion is used as stomachic. A decoction is used as emenagogue.

An infusion of a handful in a liter of water is used against renal diseases and as diuretic.

As tonic and source of protein. It is eaten as food.

An oil extracted from seeds is used as emollient against muscle pains.

The same use and indications as above. 


\begin{tabular}{lll}
\hline $\begin{array}{l}\text { FAMILY } \\
\text { Scientific name } \\
\text { Popular name(s) }\end{array}$ & Part used & Indication and form of use \\
\hline $\begin{array}{l}\text { LOASACEAE } \\
\text { Aosa rupestris (Gardner) Weigend }\end{array}$ & Roots & $\begin{array}{l}\text { Against uterine, ovarian and prostates inflammations. A } \\
\text { decoction of a handful in a liter of water or a maceration } \\
\text { in "cachaça". It is used as tea or "as water" until } \\
\text { symptoms disappear. It is indicated also to to reduce the } \\
\text { size of mammary glands and testicles. }\end{array}$
\end{tabular}

\section{LOGANIACEAE}

Spigelia anthelmia L.

Arapabaca, lombrigueira, pimentad'água

Strychnos atlantica Krukoff \& Barneby Capitãozinho

Strychnos parvifolia A.DC.

Capitãozinho, capitãozinho-preto, capitão, carrasco-preto

Strychnos trinervis (Vell.) Mart.

Capitão-preto, esporão-de-galo, cipó-

cruzeiro, quina-cruzeiro, quina

LORANTHACEAE

Phthirusa pyrifolia (Kunth) Eichler

Erva-de-passarinho

MALPIGHIACEAE

Byrsonima crassifolia (L.) Kunth

Murici-da-praia, murici-do-cerrado

Byrsonima sericea DC.

Murici-da-mata

Byrsonima gardneriana A. Juss.

Muricizinho

Byrsonima verbascifolia (L.) DC.

Murici-de-tabuleiro, douradinha-falsa

* Malpighia glabra L.

Acerola

MALVACEAE-BOMBACOIDEAE

Ceiba glaziovii (Kuntze)K. Schum.

Barriguda-de-espinho

Pseudobombax marginatum (A. St.-Hil., Stem-bark

Juss. \& Cambess.) A. Robyns

Embiratanha

MALVACEAE-MALVOIDEAE

*Abelmoschus esculentus (L.) Moench Seeds
Quiabo

Gaya aurea A.St.-Hil. Leaves

Malva-balãozinho

*Gossypium barbadense L. Seeds

Algodoeiro, algodão

${ }^{*}$ Gossypium herbaceum L.

Algodão

Herissantia crispa $\mathrm{L}$.

Malvaísco

Herissantia tiubae (K. Schum.)

Brizicky

Lava-prato, mela-bode

*Hibiscus rosa-sinensis L. Leaves

Papoula, hibisco

Pavonia cancellata (L.) Cav.

Malva, malva-de-rama
Entire plant

Leaves and stem-

bark

Roots

Leaves and stem-

bark

Roots

Leaves, stem-

bark, roots

Leaves

Bark and leaves

Stem-bark

Leaves

Stem-bark

Fruits

Leaves and stembark

Leaves and

flowers

Roots

Leaves

Leaves
An infusion against coughs. The juice against verminosis.

An infusion is used against coughs, gastrointestinal disorders as diarrheas, dermatitis and also against snake bite.

A decoction against fevers and diarrheas, syphilis and kidney diseases.

A decoction is used against external ulcers and inflammations.

The same uses and indications as above.

The juice is indicated as source of vitamin $\mathrm{C}$ against flu.

Against rheumatism and edemas. A decoction of a handful in a liter of water. It is used in wash for the affected area until the symptoms disappear.

A decoction is used against inflammations.

Roasted and grounded "as café". It is used as antirheumatic and laxative.

An infusion or decoction is used as carminative and digestive.

The decoction is used against venereal diseases and inflammations of urinary throat. The grounded seeds are used externally against burned skin.

A decoction and syrup are used against asthmas and hepatitis.

A decoction is used against affections in the respiratory tracts and coughs.

An infusion is indicated against fevers and flu.

An infusion is used as laxative and also for reduce the weight.

It is used as poultice against furunculous. 


\section{FAMILY}

Scientific name

Popular name(s)

Sida carpinifolia L. f.

Relógio-vassoura

Sida cordifolia L.

Malva-veludo, malva-branca, malva, malvão

Sida spinosa L.

Malva-lanceta, malva-relógio

Fryxell

Ervanço, malva-preta, guaxima

Urena lobata L.

Malva-rosa, malva-roxa, carrapicho-de- Roots

cavalo

MALVACEAE-BYTTNERIOIDEAE

Guazuma ulmifolia Lam.

Mutamba

Melochia pyramidata L.

Malva-roxa

Melochia tomentosa L.

Malva-preta

*Theobroma cacao L.

Cacau

MALVACEAE-STERCULIOIDEAE Sterculia striata A.St.-Hil. \& Naudin Chichá

Waltheria indica L.

Malva, malva-branca

Waltheria viscosissima A.St- Hil

Malva-preta

MALVACEAE-TILIOIDEAE

Luehea divaricata Mart.

Açoita-cavalo

Triumfetta rhomboidea Jacq

Carrapicho-de-cavalo

Triumfetta semitriloba $\mathrm{L}$.

Carrapicho

MARANTACEAE

Ischnosiphon rotundifolius (Poepp. \&

Endl.) Körn.

Surucucu

MARCGRAVIACEAE

Leaves

Leaves

Leaves

Leaves

Leaves

Leaves

Roots

Seeds

Leaves

Leaves

Leaves

Leaves

Leaves

\section{Part used Indication and form of use}

Entire plant

Leaves

Entire plant

Flowers

Stem-bark

Stem-bark

Stem-bark

Leaves wash in the affected skin. affected area. olive oil. ulcers. skin diseases. furunculous. furunculous. against coughs and flu. hepatitis and inflammation.

The same use as above.

Used against snake bite.
It is used as poultice against furunculous and as emollient.

Against acnes. An infusion of a spoonful in a cup of water. It is used as wash in the affected skin. In the treat of coughs and leucorrhea. The same recipe as above. It is drunk as tea. As syrup, a spoonful is drunk four times a day until the symptoms disappear.

As anti-asthmatic, against flu and respiratory diseases. An infusion of a spoonful in a cup of water. It is used as

As emollient and against external ulcers and insect bites. The leaves in hot butter or olive oil as poultice in

Against bronchitis, coughs and asthmas. An infusion of a spoonful in a cup of water. It is drunk as tea.

As emollient. It is used as poultice with hot butter or

A decoction or infusion is used against asthmas, bronchitis and as antiseptic oral and as expectorant. The topic use is indicated as emollient.

The infusion is used as diuretic.

The decoction of a handful in a liter of water as hair tonic. It is used in baths against dandruffs and external

Against coughs and bronchitis. A decoction of a handful in half liter of water or as syrup. It is drunk as tea three times a day until the symptoms disappear.

A decoction is used to facilitate in the childbirth.

Against inflammations in the throat.

A decoction is used againts dysenteries.

Dried and powdered is used as stomachic. The oil extracted from the seeds is used against hemorrhoids and

The topical use with hot butter or olive oil against

Against syphilis, coughs and bronchitis and external ulcers and acnes. A decoction of a handful in half liter of water or as syrup. It is drunk as tea three times a day until the symptoms disappear. The topical use against

A decoction of a handful in half liter of water or as syrup

It is used in maceration as "garrafada" against anemias,

The external use is indicated against wounds. 


\begin{tabular}{|c|c|c|}
\hline $\begin{array}{l}\text { FAMILY } \\
\text { Scientific name } \\
\text { Popular name(s) }\end{array}$ & Part used & Indication and form of use \\
\hline $\begin{array}{l}\text { Norantea brasiliensis Choisy } \\
\text { Norântea, agarra-pé } \\
\text { MELIACEAE }\end{array}$ & $\begin{array}{l}\text { Leaves and } \\
\text { flowers }\end{array}$ & The decoction is used against cardiac diseases. \\
\hline $\begin{array}{l}\text { Carapa guianensis Aubl. } \\
\text { Andiroba }\end{array}$ & $\begin{array}{l}\text { Stem-bark } \\
\text { Seeds }\end{array}$ & $\begin{array}{l}\text { A decoction against fevers, rheumatism, and external } \\
\text { ulcers. } \\
\text { A decoction of grounded seeds. It is used in baths against } \\
\text { pediculosis. }\end{array}$ \\
\hline $\begin{array}{l}\text { Cedrela odorata } \mathrm{L} . \\
\text { Cedro }\end{array}$ & Stem-bark & A decoction against venereal diseases. \\
\hline $\begin{array}{l}\text { Guarea guidonia (L.) Sleumer } \\
\text { Jitó, macaqueiro }\end{array}$ & Stem-bark & A decoction against verminoses and as abortive. \\
\hline $\begin{array}{l}\text { * Melia azedarach } \mathrm{L} . \\
\text { Lírio } \\
\text { MENISPERMACEAE }\end{array}$ & Flowers & The syrup is used against flu and hypertension. \\
\hline $\begin{array}{l}\text { Chondrodendron platiphyllum A.St.- } \\
\text { Hil. (Miers) }\end{array}$ & Entire plant & As poisonous. \\
\hline $\begin{array}{l}\text { Cissampelos glaberrima A.St.-Hil. } \\
\text { Parreira, abuta }\end{array}$ & Roots & $\begin{array}{l}\text { An infusion or decoction against coughs, bronchitis and } \\
\text { respiratory diseases. }\end{array}$ \\
\hline $\begin{array}{l}\text { Cissampelos sympodialis Eichler } \\
\text { Milona } \\
\text { MONIMIACEAE }\end{array}$ & Roots & The same uses and indications as above. \\
\hline $\begin{array}{l}* * \text { Peumus boldus Molina } \\
\text { Boldo, boldo-do-chile }\end{array}$ & Leaves & $\begin{array}{l}\text { An infusion of a handful in a liter of water. It is used as } \\
\text { tea or cold against liver diseases and as digestive and } \\
\text { stomachic. }\end{array}$ \\
\hline $\begin{array}{l}\text { MORACEAE } \\
\text { *Artocarpus communis J.R. Forst. \& G. } \\
\text { Forst. } \\
\text { Fruta-pão }\end{array}$ & Leaves & $\begin{array}{l}\text { A decoction is used in baths against furuncles. The leaves } \\
\text { "in natura" is used as poultices against rheumatisms. }\end{array}$ \\
\hline $\begin{array}{l}\text { *Artocarpus integrifolia } \mathrm{L} . \mathrm{f} . \\
\text { Jaca }\end{array}$ & Seeds & It is cooked and used as aphrodisiac. \\
\hline $\begin{array}{l}\text { Brosimum gaudichaudii Trécul } \\
\text { Mama-de-cadela }\end{array}$ & $\begin{array}{l}\text { Stem-bark and } \\
\text { leaves }\end{array}$ & The decoction is used against vitiligo and skin diseases. \\
\hline $\begin{array}{l}\text { Dorstenia brasiliensis Lam. } \\
\text { Contra-erva, carapiá } \\
\text { MORINGACEAE }\end{array}$ & Roots & A decoction or as syrup against coughs and bronchitis. \\
\hline $\begin{array}{l}\text { *Moringa oleifera Lam. } \\
\text { Moringa }\end{array}$ & Fruits & $\begin{array}{l}\text { The decoction against skin diseases. It is used in bath or } \\
\text { for wash the affected area. }\end{array}$ \\
\hline MUSACEAE & Leaves & Against diseases of respiratory system and articulations. \\
\hline $\begin{array}{l}\text { *Musa paradisiaca } \mathrm{L} . \\
\text { Bananeira, banana }\end{array}$ & $\begin{array}{l}\text { Leaves } \\
\text { Fruits }\end{array}$ & $\begin{array}{l}\text { A decoction against external ulcers and burned skin. } \\
\text { As food in nature against vascular diseases. The fruit } \\
\text { grilled with the epicarp is used against diarrheas and } \\
\text { dysenteries. }\end{array}$ \\
\hline $\begin{array}{l}\text { MYRISTICACEAE } \\
* * \text { Myristica fragrans Houtt. } \\
\text { Noz-moscada } \\
\text { MYRTACEAE }\end{array}$ & Seeds & $\begin{array}{l}\text { A decoction is used against rheumatism and digestive } \\
\text { diseases. }\end{array}$ \\
\hline $\begin{array}{l}\text { *Campomanesia aromatica (Aubl.) } \\
\text { Griseb. } \\
\text { Guabiraba-amarela }\end{array}$ & Leaves & The decoction is used for heart diseases. \\
\hline $\begin{array}{l}\text { *ucalyptus globulus Labill. } \\
\text { Eucalipto }\end{array}$ & Leaves & $\begin{array}{l}\text { An infusion is used against fevers and colds. A decoction } \\
\text { is used as inhalation against bronchitis, sinusitis and } \\
\text { colds. }\end{array}$ \\
\hline $\begin{array}{l}\text { Eugenia citrifolia } \text { Poir. } \\
\text { Araçá-verdadeiro }\end{array}$ & Leaves & $\begin{array}{l}\text { A decoction is used against migraine and cardiac } \\
\text { problems. }\end{array}$ \\
\hline $\begin{array}{l}\text { Eugenia dysenterica DC. } \\
\text { Cagaita }\end{array}$ & Leaves & $\begin{array}{l}\text { The decoction or infusion is drunk against diarrheas and } \\
\text { dysenteries. }\end{array}$ \\
\hline $\begin{array}{l}\text { Eugenia uniflora } \mathrm{L} . \\
\text { Pitanga }\end{array}$ & Leaves & The same uses and indications as above. \\
\hline $\begin{array}{l}\text { * Myrciaria cauliflora (Mart.) O. Berg } \\
\text { Jabuticaba }\end{array}$ & $\begin{array}{l}\text { Leaves and } \\
\text { stem-bark }\end{array}$ & $\begin{array}{l}\text { A decoction is drunk against diarrheas and dysenteries. } \\
\text { The syrup is used against coughs and bronchitis. }\end{array}$ \\
\hline
\end{tabular}




\section{FAMILY}

Scientific name

Popular name(s)

* Myrciaria jaboticaba (Vell.) O. Berg Stem-bark and

Jaboticabeira

Psidium guajava L.

Goiaba

Psidium guineense Sw.

Araçá, araçá do campo

*Syzygium aromaticum (L.) Merr. \& Flower-buds

L.M. Perry

Cravo-da-índia, cravo-do-reino

*Syzygium cumini (L.) Skeels

Azeitona-roxa

NYCTAGINACEAE

Boerhavia coccinea Mill.

Pega-pinto, batata-de-porco

Boerhavia repens $\mathrm{L}$.

Pega-pinto

Guapira laxiflora (Choisy) Lundell

João-mole

Guapira pernambucensis (Casar.)

Lundell.

João-mole

*Mirabilis jalapa L.

Bonina

Pisonia tomentosa Casar.

João-mole, pau-de-lepra, pau-mole

NYMPHAEACEAE

Nymphaea alba L.

Aguapé-branco, ninféia-branca, lírio-

d'água

Nymphaea pulchella DC.

Aguapé-branco

Nymphaea rudgeana G. Mey.

Aguapé-branco

OCHNACEAE

Ouratea hexasperma (A.St.-Hil.) Baill. Fruits

Batiputá

Ouratea parvifolia (A.St.-Hil.) Engler

Batiputá

OLACACEAE

Ptychopetalum olacoides Benth.

Muirapuama

Ximenia americana $\mathrm{L}$.

Ameixa

ONAGRACEAE

Ludiwigia sp.

\section{ORCHIDACEAE}

Cathasetum sp.

Banana-brava

OXALIDACEAE

*Averrhoa carambola L. Leaves

Carambola

PAPAVERACEAE

Argemone mexicana L.

Cardo-santo

\section{Indication and form of use}

leaves

Leaves

Leaves

Leaves

Roots

Roots

Roots

Stem-bark

Flowers

Seeds

Stem-bark

Entire plant

Entire plant

Entire plant

Fruits

Roots

Stem-bark

Flowers and

fruits

Fruits

Seeds

Latex diarrheas. symptoms disappear. infections. diseases and as aphrodisiac. pains. and acnes. aphrodisiac. and prostatic inflammations. stomachache. and liver diseases. tea after meals.
The syrup or decoction is used against coughs and

The same use and indication as Eugenia dysenterica.

The same use and indication as Eugenia dysenterica.

It is used against toothaches, halitosis and oral diseases.

The decoction is used against diabetes and renal problems.

As diuretic and against liver diseases. A decoction of a handful in a liter of water. It is drunk as tea until the

The infusion or decoction are used against kidneys

The decoction is drunk against rheumatism and sexual

It is used as caustic against warts.

The infusion against leucorrhea. It is used 2-3 times daily. Dropped into the ears against inflammations and

The grounded seeds are applied externally against ulcers

A decoction is used against diarrheas and leprosies.

A decoction is used against diarrhea, cystitis, urinary inflammations and elephantiasis.

A decoction against diarrheas and inflammations of prostate, treat urinary and ovaries.

The same uses and indications as above.

The oil extracted from the fruits by the heat against ear pains. It is dropped into the ears until the pain disappears.

The same uses and indications as above.

The decoction is drunk against rheumatism and as

The maceration is used as diuretic and against ovarian

The decoction is used against liver diseases and as

It is macerated is used to extract spines.

An infusion or decoction is used against urinary, kidney

As purgative, laxative and digestive. An infusion or decoction of a teaspoon in a cup of water. It is drunk as

Against conjunctivitis. The latex is dropped into the eyes. 


\begin{tabular}{|c|c|c|}
\hline $\begin{array}{l}\text { FAMILY } \\
\text { Scientific name } \\
\text { Popular name(s) } \\
\end{array}$ & Part used & Indication and form of use \\
\hline $\begin{array}{l}\text { PASSIFLORACEAE } \\
\text { Passiflora cincinnata Mast. } \\
\text { Maracujá-mochila, maracujá-do-mato }\end{array}$ & Leaves & $\begin{array}{l}\text { Against venereal diseases and hemorrhoids. A decoction } \\
\text { of a handful in a liter of water. It is drunk as tea. }\end{array}$ \\
\hline $\begin{array}{l}\text { *Passiflora edulis Sims } \\
\text { Maracujá }\end{array}$ & $\begin{array}{l}\text { Fruit } \\
\text { Leaves } \\
\text { Mesocarp }\end{array}$ & $\begin{array}{l}\text { The juice as sedative. } \\
\text { Against renal stones and as digestive, and diuretic. } \\
\text { It is dried and powdered and used as food against } \\
\text { diabetes. }\end{array}$ \\
\hline $\begin{array}{l}\text { Passiflora foetida } \mathrm{L} \text {. } \\
\text { Camapu, maracujá-de-estalo, maracujá- } \\
\text { catinga }\end{array}$ & $\begin{array}{l}\text { Entire plant } \\
\text { Leaves }\end{array}$ & $\begin{array}{l}\text { Against venereal diseases. A decoction of a handful in a } \\
\text { liter of water. It is drunk as tea. } \\
\text { Against hemorrhoids. The same recipe as above. It is } \\
\text { used for local baths. }\end{array}$ \\
\hline $\begin{array}{l}\text { PEDALIACEAE } \\
\text { *Sesamum indicum L. } \\
\text { Gergelim }\end{array}$ & $\begin{array}{l}\text { Leaves } \\
\text { Seeds }\end{array}$ & $\begin{array}{l}\text { An infusion against coughs and inflammations of the } \\
\text { throat. } \\
\text { Roasted and grounded is used as hypotensive and source } \\
\text { of vitamin. }\end{array}$ \\
\hline $\begin{array}{l}\text { PHYLLANTHACEAE } \\
\text { Phyllanthus claussenii Müll.Arg. } \\
\text { Quebra-pedra } \\
\text { Phyllanthus niruri L. } \\
\text { Quebra-pedra } \\
\text { PHYTOLACCACEAE } \\
\text { Microtea } \text { sp. } \\
\text { Angélica-rasteira } \\
\text { Petiveria alliacea L. } \\
\text { Tipí, guiné }\end{array}$ & $\begin{array}{l}\text { Aerial parts and } \\
\text { roots } \\
\text { Leaves } \\
\text { Roots }\end{array}$ & $\begin{array}{l}\text { The decoction is used as sedative and also to facilitate the } \\
\text { expulsion of placenta. } \\
\text { The juice is used against toot pains. } \\
\text { A decoction of a handful in a liter of water as abortive. It } \\
\text { is drunk until the menstruation appear. }\end{array}$ \\
\hline $\begin{array}{l}\text { PIPERACEAE } \\
\text { Ottonia leptostachya Kunth } \\
\text { Jaborandi }\end{array}$ & Entire plant & $\begin{array}{l}\text { Againts arthritis and as analgesic and sedative. Against } \\
\text { warts. An infusion or decoction of a handful in a liter of } \\
\text { water. It is drunk during the pain. }\end{array}$ \\
\hline $\begin{array}{l}\text { Peperomia pellucida }(\mathrm{L} .) \text { Kunth } \\
\text { Língua-de-sapo, alfavaca-de-cobra, } \\
\text { alfavaquinha-de-cobra } \\
\text { Piper aduncum L. } \\
\text { Pimenta-darda, pimenta-de-macaco }\end{array}$ & $\begin{array}{l}\text { Entire plant } \\
\text { Inflorescence }\end{array}$ & $\begin{array}{l}\text { A decoction as diuretic. It is used also against general } \\
\text { infections. } \\
\text { A decoction is used against venereal diseases and } \\
\text { infections of the urinary throat. }\end{array}$ \\
\hline $\begin{array}{l}\text { Piper arboreum Aubl. } \\
\text { Fruto de morcego, alecrim-de-angola, } \\
\text { pau-de-angola, beto-preto } \\
\text { Piper marginatum Jacq. } \\
\text { Malvaisco } \\
\text { *Piper nigrum } \text { L. } \\
\text { Pimenta do reino } \\
\text { Pothomorphe umbellata }(\text { L.) Miq. } \\
\text { Caápeba }\end{array}$ & $\begin{array}{l}\text { Inflorescence } \\
\text { Seeds } \\
\text { Inflorescence } \\
\text { Leaves }\end{array}$ & $\begin{array}{l}\text { The same indication and uses as } P \text {. aduncum and against } \\
\text { toothaches. } \\
\text { The infusion or decoction is used against coughs and as } \\
\text { tonic for appetite. } \\
\text { A decoction against liver and kidney diseases, migraine } \\
\text { and headaches. } \\
\text { Smashed as poultice against external ulcers. }\end{array}$ \\
\hline $\begin{array}{l}\text { PLANTAGINACEAE } \\
\text { Plantago major L. } \\
\text { Tanchagem } \\
\text { PLUMBAGINACEAE } \\
\text { Plumbago scandens L. } \\
\text { Louco }\end{array}$ & Entire plant & $\begin{array}{l}\text { A decoction or infusion is used against diarrheas and } \\
\text { dysenteries, in gargling it is used against tonsillitis. } \\
\text { As an analgesic in arthritis and as sedative. An infusion } \\
\text { or decoction of a handful in a liter of water. It is drunk } \\
\text { during the pain. } \\
\text { The ground leaves are placed on warts as poultice. }\end{array}$ \\
\hline POACEAE & & \\
\hline
\end{tabular}


FAMILY

Scientific name

Popular name(s)

*Andropogon citratus DC. ex Nees Leaves

Capim-santo, capim-limão

Andropogon leucostachyus Kunth

Capim-açu, capim-barba-de-bode

*Coix lacryma-jobi L.

Capim de contas, conta-de-nossa-

senhora

*Oryza sativa L.

Arroz

Panicum sp.

Sete-sangrias, capim panasco

*Phalaris canariensis L.

Alpiste

Piresia leptophylla Soderstr.

Acanfor-de-remédio

*Zea mays L.

Milho

POLYGALACEAE

Bredemeyera floribunda Willd.

Pacari, Pau-rendoso

Polygala gracilis Kunth

Arrozinho

Polygala martiana A.W.Benn.

Poaia, ipecacuanha

Polygala paniculata L.

Barba-de-são-pedro, alcaçuz, arrozinho

Polygala spectabilis DC.

Caninana

Polygala violacea Aubl.

Erva-iodeque

POLYPODIACEAE

Microgramma vacciniifolia (Langsd. \& Entire plant

Fisch.) Copel.

Salambaia, samambaia

POLYGONACEAE

Polygonum punctatum Elliott

Pimenta-d'agua

\section{PONTEDERIACEAE}

Eichhornia paniculata (Spreng.) Solms Leaves

Mureré, aguapé

PORTULACACEAE

Portulaca oleracea L.

Bredo, beldroega

Talinum paniculatum (Jacq.) Gaertn.

Bredo

Talinum triangulare (Jacq.) Willd. Leaves

Bredo, língua-de-vaca

PUNICACEAE

*Punica granatum L.

Romã, romanzeira

Roots

Stem-bark

Roots

Leaves

Seeds

Seeds

Entire plant

Seeds

Leaves and entire

plant

Stigma and seeds

Roots-bark

Roots

Roots

Roots

Roots

Entire plant

Fruit epicarp

Leaves

\section{Indication and form of use}

The infusion is used against diarrheas, colds, headaches, muscular pains, fevers, hypertension and general pains and as diuretic.

The juice is used as sedative.

The decoction is used against depression and as diuretic.

A decoction as diuretic and against infections.

The seeds cookd is indicated against intestinal infections.

A decoction or an infusion is used against liver, kidney and urinary diseases.

The infusion is used against kidneys infections.

The decoction is used against respiratory and renal diseases, and also against spinal problems.

Against enuresis, measles.

The alcoholic extract in topical use is indicated against dermatitis and insect bites.

As diuretic, emetic and expectorant. An infusion or decoction of a handful in a liter of water. It is drunk substituting the water until the symptoms disappear and against blenorrheas.

The same uses and indications as $P$. paniculata.

As a diuretic, emetic and expectorant and against blenorrheas. An infusion or decoction of a handful in a liter of water. It is drunk substituting the water until the symptoms disappear. Against snake bites. The roots are eaten and placed above the affected area.

Against snake bite. The roots are eaten and placed above the affected area.

The same uses and indications as above.

An infusion is used against diverse types of swelling.

A decoction against bronchitis and coughs. As syrup is used as expectorant, digestive and stomachic. The external use in baths or washes against seborrhea, dandruffs and dermatitis.

The decoction is used against hemorrhoids.

Against hemorrhoids and as vermifuge A handful as decoction in a liter of water. It is used before breakfast once only.

A infusion is used against prostate inflammation.

As laxative. It is cooked or eating as salad.

The decoction is used as gargling against infections and inflammations of the tract respiratory.

A decoction of a handful in a liter against diarrheas. 


\begin{tabular}{|c|c|c|}
\hline $\begin{array}{l}\text { FAMILY } \\
\text { Scientific name } \\
\text { Popular name(s) }\end{array}$ & Part used & Indication and form of use \\
\hline Gouania latifolia Reissek & $\begin{array}{l}\text { Inner bark and } \\
\text { leaves }\end{array}$ & The decoction is used against uterine inflammations. \\
\hline $\begin{array}{l}\text { Zizyphus cotinifolia Reiss. } \\
\text { Juazeiro }\end{array}$ & Stem-bark & $\begin{array}{l}\text { As toothpaste in treatment of teeth and gum. It is } \\
\text { powdered and used directly to brush the teeth. Against } \\
\text { dandruff. The same recipe as above. It is used as washes } \\
\text { of the hairs. }\end{array}$ \\
\hline $\begin{array}{l}\text { Zizyphus joazeiro Mart. } \\
\text { Juazeiro, Joá, joazeiro, juá, juá-de- } \\
\text { espinho }\end{array}$ & Roots & The same uses and recipe as above. \\
\hline RUBIACEAE & & \\
\hline $\begin{array}{l}\text { Chiococca alba }(\mathrm{L} .) \text { Hitchc. } \\
\text { Cipó-cruz, caninana, cainco }\end{array}$ & Roots & $\begin{array}{l}\text { A decoction of a handful in a liter of water. It is used } \\
\text { against rheumatism and indigestions. It is used also } \\
\text { against snake bite. }\end{array}$ \\
\hline $\begin{array}{l}\text { * Coffea arabica } \mathrm{L} \\
\text { Café }\end{array}$ & Seeds & $\begin{array}{l}\text { The infusion is used against vertigo and somnolence. The } \\
\text { strong infusion is indicated as abortive. }\end{array}$ \\
\hline $\begin{array}{l}\text { Coutarea hexandra (Jacq.) K.Schum. } \\
\text { Quina-quina }\end{array}$ & Stem-bark & $\begin{array}{l}\text { A decoction of a handful in a liter is used as febrifuge. It } \\
\text { is used against malaria, bronchitis and hepatitis. The } \\
\text { external use in bath is applied against dandruffs. }\end{array}$ \\
\hline $\begin{array}{l}\text { Emmeorhiza umbellata (Spreng.) K. } \\
\text { Schum. } \\
\text { Vassourinha-de-botão }\end{array}$ & $\begin{array}{l}\text { Flowers and } \\
\text { fruits }\end{array}$ & $\begin{array}{l}\text { A decoction is used against food intoxication and as } \\
\text { digestive. }\end{array}$ \\
\hline Genipa americana $\mathrm{L}$. & Fruit & It is used as tonic against anemias. \\
\hline Jenipapo & Leaves & The infusion is drunk against liver diseases. \\
\hline $\begin{array}{l}\text { Guettarda angelica Müll.Arg. } \\
\text { Angélica-brava, angélica-do-mato }\end{array}$ & Roots & $\begin{array}{l}\text { Against menstrual spasms, constipation and fevers. An } \\
\text { infusion or decoction of a small piece in a cup of water. } \\
\text { It is drunk as tea during the pains. }\end{array}$ \\
\hline $\begin{array}{l}\text { Guettarda platypoda } \mathrm{DC} \text {. } \\
\text { Angélica-do-mato }\end{array}$ & Roots & The same indication and uses as above. \\
\hline $\begin{array}{l}\text { Guettarda rhabdocalyx Müll.Arg. } \\
\text { Angélica-brava }\end{array}$ & Roots & The same indication and uses as above. \\
\hline $\begin{array}{l}\text { Richardia brasiliensis Gomes } \\
\text { Ervanço, poaia, ipeca }\end{array}$ & Roots & $\begin{array}{l}\text { Against hemorrhoids and as vermifuge. A handful as } \\
\text { decoction in a liter of water. It is used before breakfast } \\
\text { once only. }\end{array}$ \\
\hline $\begin{array}{l}\text { Richardia grandiflora (Cham. \& } \\
\text { Schltdl.)Steud. } \\
\text { Ervanço, poaia, ipeca-mirim }\end{array}$ & Roots & The same indication and uses as above. \\
\hline $\begin{array}{l}\text { Psychotria bracteocardia (DC.) } \\
\text { Müll.Arg. } \\
\text { Mata-rato }\end{array}$ & Entire plant & It is used with food to kill mouses. \\
\hline $\begin{array}{l}\text { Psychotria ipecacuanha (Brot.) Stokes } \\
\text { Ipecacoanha }\end{array}$ & Roots & The decoction is used agains fevers and malaria. \\
\hline $\begin{array}{l}\text { Salzmannia nitida } \text { DC. } \\
\text { Cainca-vermelha }\end{array}$ & Stem-bark & A decoction as febrifuge and used against tooth pains. \\
\hline $\begin{array}{l}\text { Spermacoce verticillata } \text { L. var. } \\
\text { verticillata } \\
\text { Vassourinha-de-botão }\end{array}$ & Roots & $\begin{array}{l}\text { As vermifuge and against hemorrhoids. A decoction of a } \\
\text { handful in a half of liter of water. It is used once before } \\
\text { the breakfast. }\end{array}$ \\
\hline $\begin{array}{l}\text { Tocoyena brasiliensis Mart. } \\
\text { Jenipapo-bravo }\end{array}$ & Leaves & $\begin{array}{l}\text { Against rheumatisms. The leaves are used as poultice in } \\
\text { the affected area with hot olive oil or butter. }\end{array}$ \\
\hline $\begin{array}{l}\text { Tocoyena formosa (Cham. \& } \\
\text { Schltdl.)K.Shum. } \\
\text { Jenipapim, jenipapo-bravo } \\
\text { RUTACEAE }\end{array}$ & Leaves & The same indications and uses as above. \\
\hline *Citrus x limon (L.)Osbeck & Leaves & An infusion is used against flu and colds. It is used to \\
\hline Limão & Fruit & wash the eyes against conjunctivitis. \\
\hline *Citrus maxima (Burm. ex Rumph.) & Leaves and fruit & The infusion of a handful in a liter of water or maceration \\
\hline Merr. & skin & in wine. It is used as sedative, stomachic and digestive. \\
\hline Laranjeira & Flowers & An infusion of a spoonful as sedative. \\
\hline $\begin{array}{l}\text { *Citrus medica } \mathrm{L} \\
\text { Limoeiro }\end{array}$ & Fruit & The juice is used against flu and coughs. \\
\hline $\begin{array}{l}\text { Ertela trifolia (L.) Kuntze } \\
\text { Alfavaca-de-cobra }\end{array}$ & Aerial parts & A decoction or infusion against fevers and malaria \\
\hline
\end{tabular}




\begin{tabular}{|c|c|c|}
\hline $\begin{array}{l}\text { FAMILY } \\
\text { Scientific name } \\
\text { Popular name(s) } \\
\end{array}$ & Part used & Indication and form of use \\
\hline $\begin{array}{l}\text { Fagara rhoifolia (Lam.) Engl. } \\
\text { Limãozinho }\end{array}$ & $\begin{array}{l}\text { Stem-bark } \\
\text { Stem-roots }\end{array}$ & $\begin{array}{l}\text { A decoction or infusion against fevers and as stomachic. } \\
\text { A decoction against rheumatism. }\end{array}$ \\
\hline $\begin{array}{l}\text { Pilocarpus jaborandi Holmes } \\
\text { Jaborandi, joão-barondi }\end{array}$ & $\begin{array}{l}\text { Stem-bark and/or } \\
\text { leaves } \\
\text { Entire plant }\end{array}$ & $\begin{array}{l}\text { A decoction as febrifuge and sudorific. It is used against } \\
\text { tooth pains. } \\
\text { As poisonous. }\end{array}$ \\
\hline $\begin{array}{l}\text { Pilocarpus microphyllus Stapf } \\
\text { Jaborandi }\end{array}$ & Entire plant & The same uses and indications as above. \\
\hline $\begin{array}{l}\text { *Ruta graveolens } \mathrm{L} . \\
\text { Arruda } \\
\text { SAPINDACEAE }\end{array}$ & Aerial parts & $\begin{array}{l}\text { An infusion of a handful in a liter of water or maceration } \\
\text { in wine. It is as used as abortive and against amenorrhea. }\end{array}$ \\
\hline $\begin{array}{l}\text { Allophylus edulis (A.St.-Hil., Cambess. } \\
\text { \& A.Juss.) Radlk. } \\
\text { Fruta-de-paraó }\end{array}$ & $\begin{array}{l}\text { Bark } \\
\text { Leaves }\end{array}$ & $\begin{array}{l}\text { The decoction against external ulcers. } \\
\text { An infusion against kidney diseases. }\end{array}$ \\
\hline $\begin{array}{l}\text { Allophylus quercifolius Radlk. } \\
\text { Cardiospermum corindum L. } \\
\text { Para-tudo, balãozinho, camapú, saco- } \\
\text { de-padre }\end{array}$ & $\begin{array}{l}\text { Leaves } \\
\text { Entire plant }\end{array}$ & $\begin{array}{l}\text { An infusion is used against ulcers. } \\
\text { Against liver disorders and rheumatisms. As tonic for } \\
\text { memory, diuretic and emenagogue. An infusion or } \\
\text { decoction of a handful in a liter of water. It is drunk as tea } \\
\text { until the symptoms disappear. }\end{array}$ \\
\hline $\begin{array}{l}\text { Cardiospermum oliveirae M.S.Ferrucci } \\
\text { Cipó-cruapé, timbó }\end{array}$ & Aerial parts & $\begin{array}{l}\text { A decoction is used against external ulcers, inflammations } \\
\text { and tumors. }\end{array}$ \\
\hline Paullinia pinnata $\mathrm{L}$ & Seeds & An infusion against hydropsies. \\
\hline Mata-fome, cururu-apé & Leaves & $\begin{array}{l}\text { An infusion as ophthalmic. It is also used against uterine } \\
\text { inflammations and kidney diseases. The external uses as } \\
\text { emollient. }\end{array}$ \\
\hline $\begin{array}{l}\text { Serjania comata Radlk. } \\
\text { Ariu }\end{array}$ & Roots & A decoction is used against rheumatism. \\
\hline $\begin{array}{l}\text { Serjania lethalis A. St.-Hil. } \\
\text { Ariu }\end{array}$ & Leaves & A decoction is used against renal pain. \\
\hline $\begin{array}{l}\text { Sapindus saponaria } \mathrm{L} \text {. } \\
\text { Sabonete, jitó }\end{array}$ & Entire plant & As poisonous and used as insect repellent. \\
\hline $\begin{array}{l}\text { Serjania glabrata Kunth } \\
\text { Timbó }\end{array}$ & Entire plant & It is mixed with food to kill rats. \\
\hline $\begin{array}{l}\text { Talisia esculenta (A.St.-Hil.) Radlk. } \\
\text { Pitombeira } \\
\text { SAPOTACEAE }\end{array}$ & $\begin{array}{l}\text { Leaves and stem- } \\
\text { bark }\end{array}$ & $\begin{array}{l}\text { The decoction or as syrup against coughs and as } \\
\text { expectorant. }\end{array}$ \\
\hline $\begin{array}{l}\text { Sideroxylon obtusifolium (Roem. \& } \\
\text { Schult.) T.D. Penn. } \\
\text { Quixaba, rompe-gibão } \\
\text { SCROPHULARIACEAE }\end{array}$ & Entire plant & $\begin{array}{l}\text { Against ovarian inflammations and diabetes. A decoction } \\
\text { or maceration of a handful in a liter of water. It is drunk } \\
\text { "as water" or tea until the symptoms disappear. }\end{array}$ \\
\hline $\begin{array}{l}\text { Capraria biflora } \mathrm{L} \text {. } \\
\text { Chá-da-calçada }\end{array}$ & Roots & $\begin{array}{l}\text { The decoction as purgative, emetic, abortive and used } \\
\text { against rheumatism. }\end{array}$ \\
\hline $\begin{array}{l}\text { Scoparia dulcis L. } \\
\text { Vassourinha }\end{array}$ & Entire plant & $\begin{array}{l}\text { Against amenorrhea and as vermifuge. A decoction of a } \\
\text { handful in a liter of water. It is drunk as tea. }\end{array}$ \\
\hline & Roots & As anti-diabetic. The same recipe and use as above. \\
\hline $\begin{array}{l}\text { Stemodia foliosa Benth. } \\
\text { Meladinha }\end{array}$ & Aerial parts & $\begin{array}{l}\text { As insect repellent. The fresh plant is scrubbed on the } \\
\text { skin. }\end{array}$ \\
\hline $\begin{array}{l}\text { Stemodia maritima } \mathrm{L} . \\
\text { Meladinha } \\
\text { SELAGINELLACEAE }\end{array}$ & Aerial parts & The same use and indication as above. \\
\hline $\begin{array}{l}\text { Selaginella convoluta (Arn.) Spring } \\
\text { Mão-fechada, jericó, mão-de-papagaio. }\end{array}$ & Entire plant & $\begin{array}{l}\text { As aphrodisiac and diuretic and against amenorrhea. A } \\
\text { decoction of entire plant in two cups of water. It is used } \\
\text { as tea three times daily. }\end{array}$ \\
\hline $\begin{array}{l}\text { SIMAROUBACEAE } \\
\text { Quassia amara L. } \\
\text { Pau-amargo }\end{array}$ & Roots & Decoction or infusion against kidney and liver diseases. \\
\hline $\begin{array}{l}\text { Simaba maiana Casar. } \\
\text { Pratudo, pata-tudo } \\
\text { SMILACACEAE }\end{array}$ & Leaves & $\begin{array}{l}\text { The decoction is used against general inflammations and } \\
\text { strokes and as depurative. }\end{array}$ \\
\hline
\end{tabular}




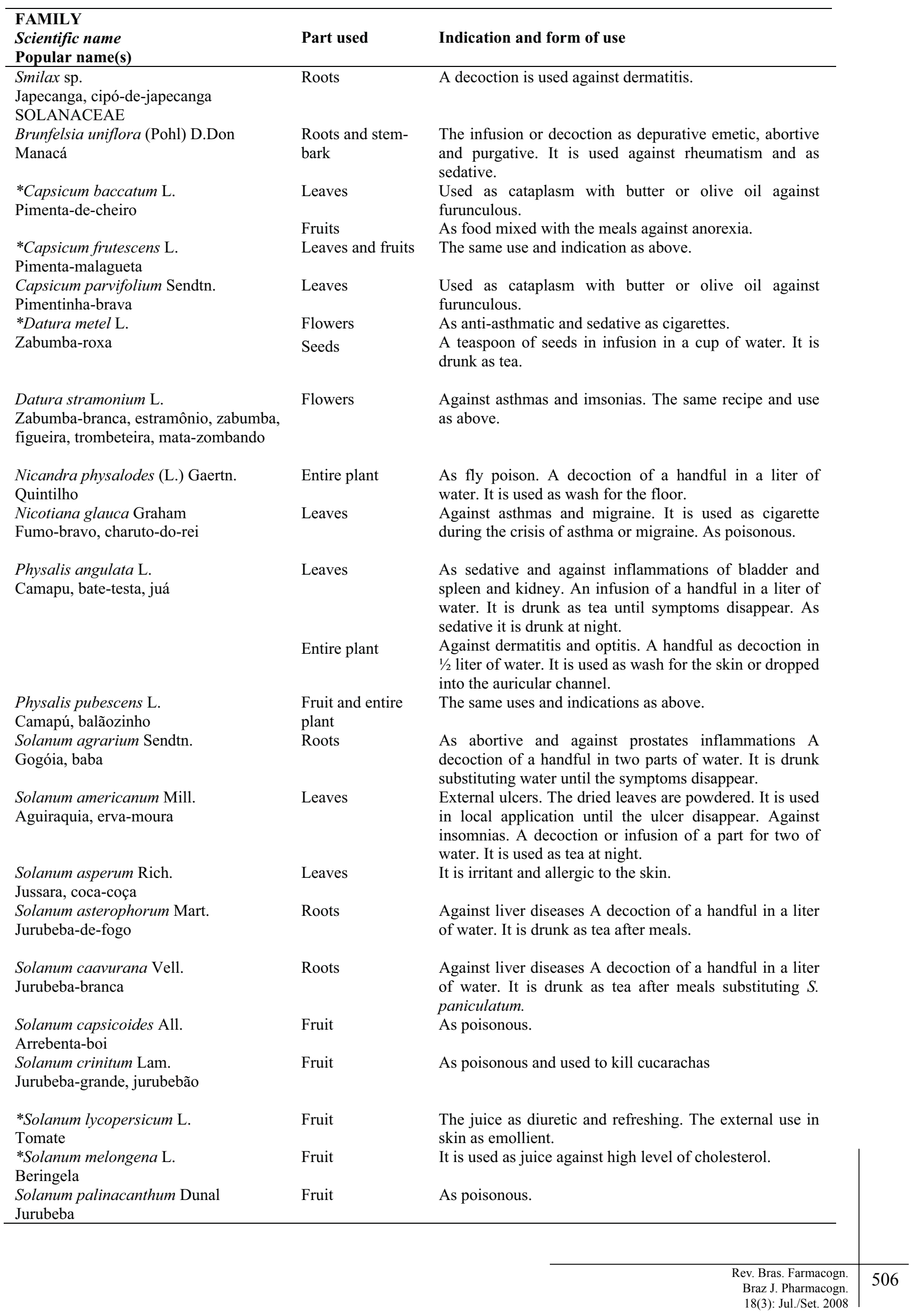




\begin{tabular}{|c|c|c|}
\hline $\begin{array}{l}\text { FAMILY } \\
\text { Scientific name } \\
\text { Popular name(s) } \\
\end{array}$ & Part used & Indication and form of use \\
\hline Solanum paludosum Moric. & Roots & The infusion is used against hepatic diseases. \\
\hline Jurubeba-brava, jurubeba-roxa & Fruit & As poisonous. \\
\hline \multirow[t]{2}{*}{$\begin{array}{l}\text { Solanum paniculatum } \mathrm{L} \text {. } \\
\text { Jurubeba, jurubeba-roxa }\end{array}$} & Roots & $\begin{array}{l}\text { As diuretic and against diseases of liver. The same recipe } \\
\text { and use as above. }\end{array}$ \\
\hline & Fruits & $\begin{array}{l}\text { As anti-anemic and against tuberculosis. The fresh juice } \\
\text { used three times a day until the symptoms disappear. }\end{array}$ \\
\hline $\begin{array}{l}\text { Solanum rhytidoandrum Sendtn. } \\
\text { Jurubeba-branca }\end{array}$ & Roots & $\begin{array}{l}\text { Against liver diseases A decoction of a handful in a liter } \\
\text { of water. It is drunk as tea after meals. }\end{array}$ \\
\hline $\begin{array}{l}\text { Solanum stipulaceum Roem. \& Schult. } \\
\text { Jussara-roxa, jurubeba-roxa }\end{array}$ & Fruits & As poisonous. \\
\hline $\begin{array}{l}\text { Solanum stramonifolium Jacq. } \\
\text { Jurubeba-branca-doce }\end{array}$ & Roots & The same indications and uses as $S$. paniculatum. \\
\hline $\begin{array}{l}\text { Solanum torvum } \mathrm{Sw} \text {. } \\
\text { Jurubeba, jurubeba-branca } \\
\text { TURNERACEAE }\end{array}$ & Roots and fruits & $\begin{array}{l}\text { The same indications and uses as substitute of } S \text {. } \\
\text { paniculatum. }\end{array}$ \\
\hline Piriqueta racemosa (Jacq.) Sweet & Entire plant & As emollient. It is used externally. \\
\hline Malva-de-vassoura & Roots & A decoction against amenorrhea and as abortive. \\
\hline \multirow[t]{2}{*}{$\begin{array}{l}\text { Turnera chamaedrifolia Cambess. } \\
\text { Chanana }\end{array}$} & Roots & $\begin{array}{l}\text { Against amenorrhea and dysmenorrheal. A decoction of } \\
\text { a handful in a liter of water. It is drunk as tea. }\end{array}$ \\
\hline & Entire Plant & $\begin{array}{l}\text { As expectorant, against bronchitis and coughs. As syrup. } \\
\text { A spoonful is drunk four times per day. }\end{array}$ \\
\hline $\begin{array}{l}\text { Turnera subulata } \mathrm{L} . \\
\text { Chanana } \\
\text { URTICACEAE }\end{array}$ & $\begin{array}{l}\text { Roots and entire } \\
\text { plant }\end{array}$ & The same uses and indications as above. \\
\hline $\begin{array}{l}\text { Laportea aestuans }(\mathrm{L} .) \text { Chew } \\
\text { Urtiga-vermelha }\end{array}$ & Roots & $\begin{array}{l}\text { Against inflammations and as anti-rheumatic. A } \\
\text { decoction of a handful in half liter of water. It is drunk as } \\
\text { tea until the symptoms disappear. }\end{array}$ \\
\hline $\begin{array}{l}\text { VELLOZIACEAE } \\
\text { Nanuza plicata (Mart.) L.B. Sm. } \\
\text { Ayenson } \\
\text { Canela-de-ema } \\
\text { VERBENACEAE }\end{array}$ & Leaves & $\begin{array}{l}\text { The infusion or decoction is used against general } \\
\text { inflammations and as tonic. }\end{array}$ \\
\hline $\begin{array}{l}\text { Lantana camara } \mathrm{L} \text {. } \\
\text { Chumbinho, camará, cambará }\end{array}$ & Leaves & $\begin{array}{l}\text { As emenagogue, diuretic, expectorant and anti- } \\
\text { rheumatic. A decoction of a handful in half liter of water. } \\
\text { It is drunk as tea until the symptoms disappear. }\end{array}$ \\
\hline $\begin{array}{l}\text { Lantana radula } \mathrm{Sw} . \\
\text { Chumbinho-branco }\end{array}$ & Leaves & The decoction is used against coughs, flu and bronchitis. \\
\hline \multirow[t]{2}{*}{$\begin{array}{l}\text { Lippia alba (Mill.) N.E. Br. } \\
\text { Erva cidreira, cidreira }\end{array}$} & $\begin{array}{l}\text { Leaves and aerial } \\
\text { parts }\end{array}$ & $\begin{array}{l}\text { The infusion or syrup is used against flu, colds and } \\
\text { hypertension and as stomachic and sedative. In baths it is } \\
\text { used against external ulcers. }\end{array}$ \\
\hline & Roots & Infusion against bad cold and coughs. \\
\hline $\begin{array}{l}\text { Lippia alnifolia Schauer } \\
\text { Alecrim-do-mato }\end{array}$ & Leaves & $\begin{array}{l}\text { The decoction or maceration in alcohol. It is used as } \\
\text { antiseptic for topical uses against dermatitis and } \\
\text { dandruffs and as antiseptic oral. }\end{array}$ \\
\hline $\begin{array}{l}\text { Lippia gracilis Schauer } \\
\text { Alecrim-pimenta, alecrim-de-serrote, } \\
\text { alecrim-da-chapada }\end{array}$ & Leaves & The same uses and indications as above. \\
\hline $\begin{array}{l}\text { Lippia microphylla Cham. } \\
\text { Alecrim-do-mato, alecrim-de-tabuleiro, } \\
\text { alecrim-pimenta }\end{array}$ & Leaves & $\begin{array}{l}\text { As antiseptic and against respiratory diseases The same } \\
\text { recipe and use as above. }\end{array}$ \\
\hline \multirow[t]{2}{*}{$\begin{array}{l}\text { Stachytarpheta cayennensis (Rich.) } \\
\text { Vahl } \\
\text { Gervão }\end{array}$} & Leaves & $\begin{array}{l}\text { Against respiratory diseases. A decoction of a handful in } \\
\text { a liter of water. It is drunk as tea until the symptoms } \\
\text { disappear. }\end{array}$ \\
\hline & Entire plant & $\begin{array}{l}\text { Against vitiligo. The same recipe as above. It is drunk } \\
\text { and used for baths. }\end{array}$ \\
\hline $\begin{array}{l}\text { Stachytarpheta elatior Schrad. ex } \\
\text { Schult. } \\
\text { Gervão }\end{array}$ & Leaves & The same recipes, uses and indications as above. \\
\hline
\end{tabular}




\section{FAMILY}

Scientific name

Popular name(s)

*Vitex agnus-castus L.

Liamba, teca

Vitex gardneriana Schauer

Jaramataia, tamanqueira

Vitex triflora $\mathrm{Vahl}$

Mama-cahorra

VIOLACEAE

Hybanthus calceolaria (L.) Schulze- Roots

Menz

Ipecacoanha, ipepacoanha, ipeca

\section{VISCACEAE}

Phoradendron strongyloclados Eichler Leaves

Erva-de-passarinho

\section{VITACEAE}

Cissus bahiensis J.A.Lombardi

Cipó-parreira

Cissus coccinea (Baker) Mart. ex

Planch.

Cipó-fogo, uva-branca, parreira-brava

Cissus decidua J.A.Lombardi

Embiratanha

Cissus erosa Rich.

Cipó-fogo, uva-branca, parreira-brava

Cissus simsiana Schult. \& Schult.f. Insulina vegetal, anil trepador

Cissus verticillata (L.) Nicolson \& C.E. Jarvis

Insulina

ZINGIBERACEAE

*Alpinia speciosa (Blume) D. Dietr. Leaves and

Colônia

*Curcuma longa L.

Gengibre-amarelo, acafrão

*Etlingera elatior (Jack) R.M. Sm.

Colônia

Renealmia sylvestris Horan.

Matarana

*Zingiber officinale Roscoe

\section{ZYGOPHYLLACEAE}

Kallstroemia maxima (L.) Hook. \& Entire plant

Arn. Puíba, rabo-de-calango

Kallstroemia tribuloides (Mart.) Steud. Puiba

Leaves

Roots

Leaves

Aerial parts

Aerial parts

Roots

Leaves parts

Flowers

Rhizome

Leaves

Flowers

Rhizome

Rhizome

Roots

\section{Indication and form of use}

An infusion against asthmas and kidney diseases.

An infusion as sedative and stomachic and against rheumatism.

The juice in topical use is indicated against warts.

As emenagogue. A decoction of a spoonful of handful in a liter of water. It is drunk as tea once a time at night. Against diarrheas and amoebas. The powder is made as pills mixed with Manihot's starch. It is used until the symptoms disappear.

The decoction against coughs and flu and as vermifuge.

Leaves or aerial
A decoction or maceration is used as aphrodisiac.

The infusion or decoction against kidney diseases. The external uses against warts and external ulcers.

The decoction is used against cancer and uterine inflammations.

The juice in topical use against warts and external ulcers. The decoction as analgesic and against leishmaniosis.

The infusion is used as diuretic against kidney diseases. The infusion or maceration of a handful in a litter of water. It is used 3 times daily against diabetes.

Against respiratory diseases and diabetes. A decoction of a handful in a liter of water. It is drunk as tea until the symptoms disappear.

As infusion and decoction in baths or against fevers and heart diseases.

The decoction is used against cardiac problems.

The powder is used against intestinal and stomachic diseases.

An infusion is drunk against flu, colds and fevers.

A maceration in alcohol is used against headaches.

The infusion is used against rheumatism and as tonic.

It is used for gargle against throat diseases. An infusion or decoction is used against bronchitis, colds, coughs and as expectorant.

Smashed with hot butter or olive oil is applied externally against furunculous

The decoction is used against cardiac diseases. 